\title{
A global and high-resolution assessment of the green, blue and grey water footprint of wheat
}

\author{
M. M. Mekonnen and A. Y. Hoekstra \\ Twente Water Centre, University of Twente, Enschede, The Netherlands \\ Received: 10 April 2010 - Published in Hydrol. Earth Syst. Sci. Discuss.: 22 April 2010 \\ Revised: 30 June 2010 - Accepted: 2 July 2010 - Published: 15 July 2010
}

\begin{abstract}
The aim of this study is to estimate the green, blue and grey water footprint of wheat in a spatially-explicit way, both from a production and consumption perspective. The assessment is global and improves upon earlier research by taking a high-resolution approach, estimating the water footprint of the crop at a 5 by 5 arc minute grid. We have used a grid-based dynamic water balance model to calculate crop water use over time, with a time step of one day. The model takes into account the daily soil water balance and climatic conditions for each grid cell. In addition, the water pollution associated with the use of nitrogen fertilizer in wheat production is estimated for each grid cell. We have used the water footprint and virtual water flow assessment framework as in the guideline of the Water Footprint Network.

The global wheat production in the period 1996-2005 required about 108 billion cubic meters of water per year. The major portion of this water $(70 \%)$ comes from green water, about $19 \%$ comes from blue water, and the remaining $11 \%$ is grey water. The global average water footprint of wheat per ton of crop was $1830 \mathrm{~m}^{3} /$ ton. About $18 \%$ of the water footprint related to the production of wheat is meant not for domestic consumption but for export. About 55\% of the virtual water export comes from the USA, Canada and Australia alone. For the period 1996-2005, the global average water saving from international trade in wheat products was $65 \mathrm{Gm}^{3} / \mathrm{yr}$.

A relatively large total blue water footprint as a result of wheat production is observed in the Ganges and Indus river basins, which are known for their water stress problems. The two basins alone account for about $47 \%$ of the blue water footprint related to global wheat production. About $93 \%$ of the water footprint of wheat consumption in Japan lies in other countries, particularly the USA, Australia and Canada.
\end{abstract}

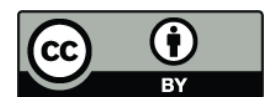

Correspondence to: M. M. Mekonnen (m.m.mekonnen@ctw.utwente.nl)
In Italy, with an average wheat consumption of $150 \mathrm{~kg} / \mathrm{yr}$ per person, more than two times the word average, about $44 \%$ of the total water footprint related to this wheat consumption lies outside Italy. The major part of this external water footprint of Italy lies in France and the USA.

\section{Introduction}

Fresh water is a renewable but finite resource. Both freshwater availability and quality vary enormously in time and space. Growing populations coupled with continued socioeconomic developments put pressure on the globe's scarce water resources. In many parts of the world, there are signs that water consumption and pollution exceed a sustainable level. The reported incidents of groundwater depletion, rivers running dry and worsening pollution levels form an indication of the growing water scarcity (Gleick, 1993; Postel, 2000; WWAP, 2009). Molden (2007) argues that to meet the acute freshwater challenges facing humankind over the coming fifty years requires substantial reduction of water use in agriculture.

The concept of "water footprint" introduced by Hoekstra (2003) and subsequently elaborated by Hoekstra and Chapagain (2008) provides a framework to analyse the link between human consumption and the appropriation of the globe's freshwater. The water footprint of a product is defined as the total volume of freshwater that is used to produce the product (Hoekstra et al., 2009). The blue water footprint refers to the volume of surface and groundwater consumed (evaporated) as a result of the production of a good; the green water footprint refers to the rainwater consumed. The grey water footprint of a product refers to the volume of freshwater that is required to assimilate the load of pollutants based on existing ambient water quality standards. The water footprint of national consumption is defined as the total amount of freshwater that is used to produce the goods consumed

Published by Copernicus Publications on behalf of the European Geosciences Union. 
by the inhabitants of the nation. The water footprint of national consumption always has two components: the internal and the external footprint. The latter refers to the appropriation of water resources in other nations for the production of goods and services that are imported into and consumed within the nation considered. Externalising the water footprint reduces the pressure on domestic water resources, but increases the pressure on the water resources in other countries. Virtual water transfer in the form of international trade in agricultural goods is increasingly recognized as a mechanism to save domestic water resources and achieve national water security (Allan, 2003; Hoekstra, 2003; De Fraiture et al., 2004; Liu et al., 2007; Oki and Kanae, 2004; Chapagain et al., 2006a; Yang et al., 2006; Hoekstra and Chapagain, 2008). Virtual water import is an instrument that enables nations to save scarce domestic water resources by importing water-intensive products and exporting commodities that require less water. On the other hand, water-abundant countries can profit by exporting water-intensive commodities.

In this report, we focus on the water footprint of wheat, which is one of the most widely cultivated cereal grains globally. It is grown on more land area than any other commercial crop and is the second most produced cereal crop after maize and a little above rice. It is believed to originate in Southwest Asia and the most likely site of its first domestication is near Diyarbakir in Turkey (Dubcovsky and Dvorak, 2007). About 90 to $95 \%$ of the wheat produced is the common wheat or bread wheat followed by durum wheat which accounts less than 5\% of world wheat production (Pena, 2002; Ekboir, 2002). Based on the growing period, wheat can be subdivided into spring and winter wheat. The difference between spring and winter wheat is accounted for by taking specific crop parameters, rooting depth and growing period.

A number of previous studies on global water use for wheat are already available. Hoekstra and Hung (2002, 2005) were the first to make a global estimate of the water use in wheat production. They analysed the period 199599 and looked at total evapotranspiration, not distinguishing between green and blue water consumption. Hoekstra and Chapagain $(2007,2008)$ improved this first study in a number of respects and studied the period 1997-2001. Still, no distinction between green and blue water consumption was made. Liu et al. (2007) made a global estimate of water consumption in wheat production for the period 1998-2002 without making the green-blue water distinction, but for the first time grid-based. Liu et al. (2009) and Liu and Yang (2010) present similar results, but now they show the green-blue water distinction. Siebert and Döll $(2008,2010)$ have estimated the global water consumption for wheat production for the same period as Liu et al. (2007, 2009), showing the greenblue water distinction and applying a grid-based approach as well. Gerbens et al. (2009) estimated the green and blue water footprint for wheat in the 25 largest producing countries. Aldaya et al. (2010) have calculated the green and blue water components for wheat in four major producing countries and also estimate international virtual water flows related to wheat trade. Aldaya and Hoekstra (2010) made an assessment of the water footprint of wheat in different regions of Italy, for the first time specifying not only the green and blue, but the grey water footprint as well.

The aim of this study is to estimate the green, blue and grey water footprint of wheat in a spatially-explicit way, both from a production and consumption perspective. We quantify the green, blue and grey water footprint of wheat production by using a grid-based dynamic water balance model that takes into account local climate and soil conditions and nitrogen fertilizer application rates and calculates the crop water requirements, actual crop water use and yields and finally the green, blue and grey water footprint at grid level. The model has been applied at a spatial resolution of 5 arc minute by 5 arc minute. The model's conceptual framework is based on the FAO CROPWAT approach (Doorenbos and Pruitt, 1977; Doorenbos and Kassam, 1979; Allen et al., 1998). The water footprint of wheat consumption per country is estimated by tracing the different sources of wheat consumed in a country and considering the specific water footprints of wheat production in the producing regions.

\section{Method}

In this study the global green, blue and grey water footprint of wheat production and consumption and the international virtual water flows related to wheat trade were estimated following the calculation framework of Hoekstra and Chapagain (2008) and Hoekstra et al. (2009). The computations of crop evapotranspiration and yield, required for the estimation of the green and blue water footprint in wheat production, have been done following the method and assumptions provided by Allen et al. (1998) for the case of crop growth under non-optimal conditions. The grid-based dynamic water balance model developed in this study for estimating the crop evapotranspiration and yield computes a daily soil water balance and calculates crop water requirements, actual crop water use (both green and blue) and actual yields. The model is applied at a global scale using a resolution level of 5 by 5 arc minute grid size (about $10 \mathrm{~km}$ by $10 \mathrm{~km}$ around the Equator). The water balance model is largely written in Python language and embedded in a computational framework where input and output data are in grid-format. The input data available in grid-format (like precipitation, reference evapotranspiration, soil, crop parameters) are converted to text-format to feed the Python code. Output data from the Python code are converted back to grid-format.

The actual crop evapotranspiration $\left(\mathrm{ET}_{a}, \mathrm{~mm} / \mathrm{day}\right)$ depends on climate parameters (which determine potential evapotranspiration), crop characteristics and soil water availability (Allen et al., 1998): 
$\mathrm{ET}_{a}[t]=K_{c}[t] \cdot K_{s}[t] \cdot \mathrm{ET}_{o}[t]$

where $K_{c}$ is the crop coefficient, $K_{s}[t]$ a dimensionless transpiration reduction factor dependent on available soil water and $\mathrm{ET}_{o}[t]$ the reference evapotranspiration $(\mathrm{mm} /$ day). The crop coefficient varies in time, as a function of the plant growth stage. During the initial and mid-season stages of the crop development, $K_{c}$ is a constant and equals $K_{c \text {,ini }}$ and $K_{c \text {,mid }}$, respectively. During the crop development and late season stages, $K_{c}$ varies linearly and linear interpolation is applied for days within the development and late growing seasons. The value of $K_{S}$ is calculated on a daily basis as a function of the maximum and actual available soil moisture in the root zone.

Following the approach as in the HBV model (Bergström, 1995; Lidén and Harlin, 2000) the amount of rainfall lost through runoff is computed as:

$R O[t]=(P[t]+I[t]) \cdot\left(\frac{S[t-1]}{S_{\max }[t-1]}\right)^{\gamma}$

in which $R O[t]$ is runoff on day $t[\mathrm{~mm}] ; P[t]$ precipitation on day $t[\mathrm{~mm}] ; I[t]$ the net irrigation depth on day $t$ that infiltrates the soil $[\mathrm{mm}]$. The value of the parameter $\gamma$ is adopted from Siebert and Döll (2010) and was set to 3 for irrigated land and to 2 for rain-fed areas.

The irrigation requirement is determined based on the root zone depletion. The actual irrigation $I[t]$ depends on the extent to which the irrigation requirement is met:

$I[t]=\alpha \cdot I R[t]$

where $\alpha$ is the fraction of the irrigation requirement that is actually met. Following the method as proposed in Hoekstra et al. (2009) and also applied by Siebert and Döll (2010), we run two scenarios, one with $\alpha=0$ (no application of irrigation, i.e. rain-fed conditions) and the other with $\alpha=1$ (full irrigation). In the second scenario we have assumed that the amount of actual irrigation is sufficient to meet the irrigation requirement. In the case of rain-fed wheat production, blue crop water use is zero and green crop water use $\left(\mathrm{m}^{3} / \mathrm{ha}\right)$ is calculated by summing up the daily values of $\mathrm{ET}_{a}(\mathrm{~mm} /$ day $)$ over the length of the growing period. In the case of irrigated wheat production, the green crop water use is assumed to be equal to the green crop water use as was calculated for the rain-fed case. The blue crop water use is then equal to the total $\mathrm{ET}_{a}$ over the growing period as simulated under the case $\alpha=1$ (full irrigation) minus the green crop water use.

The crop growth and yield are affected by the water stress. To account for the effect of water stress, a linear relationship between yield and crop evapotranspiration was proposed by Doorenbos and Kassam (1979):

$$
\left(1-\frac{Y_{a}}{Y_{m}}\right)=K_{y}\left(1-\frac{\sum \mathrm{ET}_{a}[t]}{\sum \mathrm{CWR}[t]}\right)
$$

where $K_{y}$ is a yield response factor (water stress coefficient), $Y_{a}$ the actual harvested yield [kg/ha], $Y_{m}$ the maximum yield [kg/ha], $\mathrm{ET}_{a}$ the actual crop evapotranspiration in $\mathrm{mm} /$ period and CWR the crop water requirement in $\mathrm{mm} /$ period (which is equal to $K_{c} \times \mathrm{ET}_{0}$ ). $K_{y}$ values for individual periods and the complete growing period are given in Doorenbos and Kassam (1979). The $K_{y}$ values for the total growing period for winter wheat and spring wheat are 1.0 and 1.15 , respectively. The maximum yield value for a number of countries is obtained from Ekboir (2002) and Pingali (1999). For countries with no such data the regional average value is taken. The actual yields which are calculated per grid cell are averaged over the nation and compared with the national average yield data (for the period 1996-2005) obtained from FAO (2008a). The calculated yield values are scaled to fit the national average $\mathrm{FAO}$ yield data.

The green and blue water footprints $\left(\mathrm{m}^{3} / \mathrm{ton}\right)$ are calculated by dividing the green and blue crop water use $\left(\mathrm{m}^{3} / \mathrm{ha}\right)$, respectively, by the actual crop yield (ton/ha). Both the total green and the total blue water footprint in each grid cell are calculated as the weighted average of the (green, respectively blue) water footprints under the two scenarios:

$\mathrm{WF}=\beta \cdot \mathrm{WF}(\alpha=1)+(1-\beta) \cdot \mathrm{WF}(\alpha=0)$

where $\beta$ refers to the fraction of wheat area in the grid cell that is irrigated.

The grey water footprint of wheat production is calculated by quantifying the volume of water needed to assimilate the fertilisers that reach ground- or surface water. Nutrients leaching or running off from agricultural fields are the main cause of non-point source pollution of surface and subsurface water bodies. In this study we have quantified the grey water footprint related to nitrogen use only. The grey component of the water footprint of wheat $\left(\mathrm{WF}_{g y}, \mathrm{~m}^{3} / \mathrm{ton}\right)$ is calculated by multiplying the leaching-runoff fraction $(\delta, \%)$ by the nitrogen application rate $(A R, \mathrm{~kg} / \mathrm{ha})$ and dividing this by the difference between the maximum acceptable concentration of nitrogen $\left(c_{\max }, \mathrm{kg} / \mathrm{m}^{3}\right)$ and the natural concentration of nitrogen in the receiving water body $\left(c_{\text {nat }}, \mathrm{kg} / \mathrm{m}^{3}\right)$ and by the actual wheat yield $\left(Y_{a}\right.$, ton/ha):

$\mathrm{WF}_{g y}=\left(\frac{\delta \cdot A R}{c_{\max }-c_{\text {nat }}}\right) \cdot \frac{1}{Y_{a}}$

The average green, blue and grey water footprints of wheat in a whole nation or river basin were estimated by taking the area-weighted average of the water footprint $\left(\mathrm{m}^{3} /\right.$ ton $)$ over the relevant grid cells.

The water footprints of wheat as harvested (unmilled wheat) have been used as a basis to calculate the water footprints of derived wheat products (wheat flour, wheat groats and meal, wheat starch and gluten) based on product and value fractions following the method as in Hoekstra et al. (2009).

International virtual water flows $\left(\mathrm{m}^{3} / \mathrm{yr}\right)$ related to trade in wheat products were calculated by multiplying the trade volumes (tons/yr) by their respective water footprint $\left(\mathrm{m}^{3} / \mathrm{ton}\right)$. 
The global water saving $\left(\mathrm{m}^{3} / \mathrm{yr}\right)$ through international trade in wheat products is calculated by multiplying the volume of trade (ton/yr) between two countries by the difference between the water footprint of the traded product in the importing country and the water footprint of the product in the exporting country.

The water footprint of national wheat consumption can be distinguished into an internal and external component. The internal water footprint is defined as the use of domestic water resources to produce goods and services consumed by inhabitants of the country. It is the water footprint related to production within the country minus the volume of virtual water export to other countries insofar as related to export of domestically produced products. The external water footprint is the part of the water footprint of national consumption that falls outside the nation considered. It refers to the appropriation of water resources in other nations for the production of goods and services that are imported into and consumed within the nation considered

\section{Data}

Average monthly reference evapotranspiration data at 10 arc min resolution were obtained from FAO (2008b). The 10 min data were converted to 5 arc minute resolution by assigning the $10 \mathrm{~min}$ data to each of the four $5 \mathrm{~min}$ grid cells. Following the CROPWAT approach, the monthly average data were converted to daily values by curve fitting to the monthly average through polynomial interpolation.

Monthly values for precipitation, wet days and minimum and maximum temperature with a spatial resolution of $30 \mathrm{arc}$ min were obtained from CRU-TS-2.1 (Mitchell and Jones, 2005). The $30 \mathrm{arcmin}$ data were assigned to each of the thirty-six 5 arc minute grid cells contained in the 30 arc min grid cell. Daily precipitation values were generated from these monthly average values using the CRUdGen daily weather generator model (Schuol and Abbaspour, 2007).

Wheat growing areas on a 5 arc minute grid cell resolution were obtained from Monfreda et al. (2008). For countries missing grid data in Monfreda et al. (2008) the MICRA grid database as described in Portmann et al. (2008) was used to fill the gap. The harvested wheat areas as available in grid format were aggregated to a national level and scaled to fit national average wheat harvest areas for the period 1996-2005 obtained from FAO (2008a). Grid data on irrigated wheat area per country were obtained from Portmann et al. (2008).

Crop coefficients $\left(K_{c}\right.$ 's) for wheat were obtained from Chapagain and Hoekstra (2004). Wheat planting dates and lengths of cropping seasons for most wheat producing countries and regions were obtained from Sacks et al. (2009) and Portmann et al. (2008). For some countries, values from
Chapagain and Hoekstra (2004) were used. We have not considered multi-cropping practices.

Grid based data on total available water capacity of the soil (TAWC) at a 5 arc minute resolution were taken from ISRICWISE (Batjes, 2006). An average value of TAWC of the five soil layers was used in the model.

Country-specific nitrogen fertilizer application rates for wheat have been based on Heffer (2009), FAO (2006, 2009) and IFA (2009). Globally, wheat accounts for about $17 \%$ of total fertilizer use and $19 \%$ of the total nitrogen fertilizer consumption. A number of authors show that about $45-85 \%$ of the applied nitrogen fertilizer is recovered by the plant (Addiscot, 1996; King et al., 2001; Ma et al., 2009; Noulas et al., 2004). On average, about $16 \%$ of the applied nitrogen is presumed to be lost either by denitrification or leaching (Addiscot, 1996). The reported value of nitrogen leaching varies between 2-13\% (Addiscot, 1996; Goulding et al., 2000; Riley et al., 2001; Webster et al., 1999). In this study we have assumed that on average $10 \%$ of the applied nitrogen fertilizer is lost through leaching or runoff, following Chapagain et al. (2006b). The recommended standard value of nitrate in surface and groundwater by the World Health Organization and the European Union is $50 \mathrm{mg}$ nitrate $\left(\mathrm{NO}_{3}\right)$ per litre and the standard recommended by US-EPA is $10 \mathrm{mg}$ per litre measured as nitrate-nitrogen $\left(\mathrm{NO}_{3}-\mathrm{N}\right)$. In this study we have used the standard of $10 \mathrm{mg} /$ litre of nitrate-nitrogen $\left(\mathrm{NO}_{3}-\mathrm{N}\right)$, following again Chapagain et al. (2006b). Because of a lack of data, the natural nitrogen concentrations were assumed to be zero.

Data on international trade in wheat products have been taken from the SITA database (Statistics for International Trade Analysis) available from the International Trade Centre (ITC, 2007). This database covers trade data over ten years (1996-2005) from 230 reporting countries disaggregated by product and partner countries. We have taken the average for the period 1996-2005 in wheat products trade.

\section{The water footprint of wheat from the production perspective}

The global water footprint of wheat production for the period $1996-2005$ is $1088 \mathrm{Gm}^{3} /$ year $(70 \%$ green, $19 \%$ blue, and $11 \%$ grey). Data per country are shown in Table 1 for the largest producers. The global green water footprint related to wheat production was $760 \mathrm{Gm}^{3} / \mathrm{yr}$. At a country level, large green water footprints can be found in the USA $\left(112 \mathrm{Gm}^{3} / \mathrm{yr}\right)$, China $\left(83 \mathrm{Gm}^{3} / \mathrm{yr}\right)$, Russia $\left(91 \mathrm{Gm}^{3} / \mathrm{yr}\right)$, Australia $\left(44 \mathrm{Gm}^{3} / \mathrm{yr}\right)$, and India $\left(44 \mathrm{Gm}^{3} / \mathrm{yr}\right)$. About $49 \%$ of the global green water footprint related to wheat production is in these five countries. At sub-national level (state or province level), the largest green water footprints can be found in Kansas in the USA $\left(21 \mathrm{Gm}^{3} / \mathrm{yr}\right)$, Saskatchewan in Canada $\left(18 \mathrm{Gm}^{3} / \mathrm{yr}\right)$, Western Australia $\left(15 \mathrm{Gm}^{3} / \mathrm{yr}\right)$, and North Dakota in the USA $\left(15 \mathrm{Gm}^{3} / \mathrm{yr}\right)$. The global blue water 
Table 1. Water footprint of wheat production for the major wheat producing countries. Period: 1996-2005.

\begin{tabular}{|c|c|c|c|c|c|c|c|c|c|}
\hline \multirow[t]{2}{*}{ Country } & \multirow{2}{*}{$\begin{array}{r}\text { Contribution } \\
\text { to global wheat } \\
\text { production (\%) }\end{array}$} & \multicolumn{4}{|c|}{$\begin{array}{l}\text { Total water footprint of production } \\
\qquad\left(\mathrm{Mm}^{3} / \mathrm{yr}\right)\end{array}$} & \multicolumn{4}{|c|}{$\begin{array}{l}\text { Water footprint per ton of wheat } \\
\qquad\left(\mathrm{m}^{3} / \text { ton }\right)\end{array}$} \\
\hline & & Green & Blue & Grey & Total & Green & Blue & Grey & Total \\
\hline Argentina & 2.5 & 25905 & 162 & 1601 & 27668 & 1777 & 11 & 110 & 1898 \\
\hline Australia & 3.6 & 44057 & 363 & 2246 & 46666 & 2130 & 18 & 109 & 2256 \\
\hline Canada & 3.9 & 32320 & 114 & 4852 & 37286 & 1358 & 5 & 204 & 1567 \\
\hline China & 17.4 & 83459 & 47370 & 31626 & 162455 & 820 & 466 & 311 & 1597 \\
\hline Czech Republic & 0.6 & 2834 & 0 & 900 & 3734 & 726 & 0 & 231 & 957 \\
\hline Denmark & 0.8 & 2486 & 30 & 533 & 3049 & 530 & 6 & 114 & 651 \\
\hline Egypt & 1.1 & 1410 & 5930 & 2695 & 10034 & 216 & 907 & 412 & 1536 \\
\hline France & 6.0 & 21014 & 48 & 199 & 21261 & 584 & 1 & 6 & 591 \\
\hline Germany & 3.5 & 12717 & 0 & 3914 & 16631 & 602 & 0 & 185 & 787 \\
\hline Hungary & 0.7 & 4078 & 8 & 1389 & 5476 & 973 & 2 & 331 & 1306 \\
\hline India & 11.9 & 44025 & 81335 & 20491 & 145851 & 635 & 1173 & 296 & 2104 \\
\hline Iran & 1.8 & 26699 & 10940 & 3208 & 40847 & 2412 & 988 & 290 & 3690 \\
\hline Italy & 1.2 & 8890 & 120 & 1399 & 10409 & 1200 & 16 & 189 & 1405 \\
\hline Kazakhstan & 1.7 & 33724 & 241 & 1 & 33966 & 3604 & 26 & 0 & 3629 \\
\hline Morocco & 0.5 & 10081 & 894 & 387 & 11362 & 3291 & 292 & 126 & 3710 \\
\hline Pakistan & 3.2 & 12083 & 27733 & 8000 & 47816 & 644 & 1478 & 426 & 2548 \\
\hline Poland & 1.5 & 9922 & 4 & 4591 & 14517 & 1120 & 0 & 518 & 1639 \\
\hline Romania & 0.9 & 9066 & 247 & 428 & 9741 & 1799 & 49 & 85 & 1933 \\
\hline Russian Fed. & 6.5 & 91117 & 1207 & 3430 & 95754 & 2359 & 31 & 89 & 2479 \\
\hline Spain & 1.0 & 8053 & 275 & 1615 & 9943 & 1441 & 49 & 289 & 1779 \\
\hline Syria & 0.7 & 5913 & 1790 & 842 & 8544 & 1511 & 457 & 215 & 2184 \\
\hline Turkey & 3.3 & 40898 & 2570 & 3857 & 47325 & 2081 & 131 & 196 & 2408 \\
\hline UK & 2.5 & 6188 & 2 & 2292 & 8482 & 413 & 0 & 153 & 566 \\
\hline Ukraine & 2.5 & 26288 & 287 & 1149 & 27724 & 1884 & 21 & 82 & 1987 \\
\hline USA & 10.2 & 111926 & 5503 & 13723 & 131152 & 1879 & 92 & 230 & 2202 \\
\hline Uzbekistan & 0.7 & 3713 & 399 & 0 & 4112 & 939 & 101 & 0 & 1039 \\
\hline World & & 760301 & 203744 & 123533 & 1087578 & 1279 & 343 & 208 & 1830 \\
\hline
\end{tabular}

footprint was estimated to be $204 \mathrm{Gm}^{3} / \mathrm{yr}$. The largest blue water footprints were calculated for India $\left(81 \mathrm{Gm}^{3} / \mathrm{yr}\right)$, China $\left(47 \mathrm{Gm}^{3} / \mathrm{yr}\right)$, Pakistan $\left(28 \mathrm{Gm}^{3} / \mathrm{yr}\right)$, Iran $\left(11 \mathrm{Gm}^{3} / \mathrm{yr}\right)$, Egypt $\left(5.9 \mathrm{Gm}^{3} / \mathrm{yr}\right)$ and the USA $\left(5.5 \mathrm{Gm}^{3} / \mathrm{yr}\right)$. These six countries together account for $88 \%$ of the total blue water footprint related to wheat production. At sub-national level, the largest blue water footprints can be found in Uttar Pradesh $\left(24 \mathrm{Gm}^{3} / \mathrm{yr}\right)$ and Madhya Pradesh $\left(21 \mathrm{Gm}^{3} / \mathrm{yr}\right)$ in the India and Punjab in Pakistan $\left(20 \mathrm{Gm}^{3} / \mathrm{yr}\right)$. These three states in the two countries alone account about $32 \%$ of the global blue water footprint related to wheat production. The grey water footprint related to the use of nitrogen fertilizer in wheat cultivation was $124 \mathrm{Gm}^{3} / \mathrm{yr}$. The largest grey water footprint was observed for China $\left(32 \mathrm{Gm}^{3} / \mathrm{yr}\right)$, India $\left(20 \mathrm{Gm}^{3} / \mathrm{yr}\right)$ the USA $\left(14 \mathrm{Gm}^{3} / \mathrm{yr}\right)$ and Pakistan $\left(8 \mathrm{Gm}^{3} / \mathrm{yr}\right)$.

The calculated global average water footprint per ton of wheat was $1830 \mathrm{~m}^{3} /$ ton. The results show a great variation, however, both within a country and among countries (Fig. 1). Among the major wheat producers, the highest total water footprint per ton of wheat was found for Morocco, Iran and Kazakhstan. On the other side of the spectrum, there are countries like the UK and France with a wheat water footprint of around $560-600 \mathrm{~m}^{3} /$ ton.

The global average blue water footprint per ton of wheat amounts to $343 \mathrm{~m}^{3} /$ ton. For a few countries, including Pakistan, India, Iran and Egypt, the blue water footprint is much higher, up to $1478 \mathrm{~m}^{3} /$ ton in Pakistan. In Pakistan, the blue water component in the total water footprint is nearly $58 \%$. The grey water footprint per ton of wheat is $208 \mathrm{~m}^{3} /$ ton as a global average, but in Poland it is 2.5 times higher than the global average.

Table 2 shows the water footprint related to production of wheat for some selected river basins. About 59\% of the global water footprint related to wheat production is located in this limited number of basins. Large blue water footprints can be found in the Ganges-Brahmaputra-Meghna $\left(53 \mathrm{Gm}^{3} / \mathrm{yr}\right)$, Indus $\left(42 \mathrm{Gm}^{3} / \mathrm{yr}\right)$, Yellow $\left(13 \mathrm{Gm}^{3} / \mathrm{yr}\right)$, TigrisEuphrates $\left(10 \mathrm{Gm}^{3} / \mathrm{yr}\right)$, Amur $\left(3.1 \mathrm{Gm}^{3} / \mathrm{yr}\right)$ and Yangtze river basins $\left(2.7 \mathrm{Gm}^{3} / \mathrm{yr}\right)$. The Ganges-BrahmaputraMeghna and Indus river basins together account for about $47 \%$ of the global blue and $21 \%$ of the global grey water footprint. 
Table 2. The water footprint of wheat production for some selected river basins (1996-2005).

\begin{tabular}{|c|c|c|c|c|c|c|c|c|}
\hline \multirow[t]{2}{*}{ River basin } & \multicolumn{4}{|c|}{$\begin{array}{l}\text { Total water footprint of production } \\
\left(\mathrm{Mm}^{3} / \mathrm{yr}\right)\end{array}$} & \multicolumn{4}{|c|}{$\begin{array}{l}\text { Water footprint per ton of wheat } \\
\qquad\left(\mathrm{m}^{3} / \mathrm{ton}\right)\end{array}$} \\
\hline & Green & Blue & Grey & Total & Green & Blue & Grey & Total \\
\hline $\begin{array}{l}\text { Ganges-Brahmaputra- } \\
\text { Meghna }\end{array}$ & 30288 & 53009 & 12653 & 95950 & 665 & 1164 & 278 & 2107 \\
\hline Mississippi & 79484 & 2339 & 9413 & 91236 & 1979 & 58 & 234 & 2271 \\
\hline Indus & 22897 & 42145 & 13326 & 78368 & 604 & 1111 & 351 & 2066 \\
\hline $\mathrm{Ob}$ & 51984 & 225 & 511 & 52721 & 2680 & 12 & 26 & 2718 \\
\hline Nelson-Saskatchewan & 38486 & 118 & 5691 & 44294 & 1275 & 4 & 189 & 1468 \\
\hline Tigris-Euphrates & 29219 & 10282 & 2670 & 42170 & 2893 & 1018 & 264 & 4175 \\
\hline Yellow & 17012 & 13127 & 7592 & 37731 & 695 & 536 & 310 & 1541 \\
\hline Danube & 27884 & 273 & 3579 & 31735 & 1298 & 13 & 167 & 1477 \\
\hline Volga & 25078 & 272 & 955 & 26305 & 2315 & 25 & 88 & 2429 \\
\hline Don & 24834 & 384 & 927 & 26144 & 2658 & 41 & 99 & 2799 \\
\hline Yangtze & 17436 & 2700 & 4855 & 24991 & 1112 & 172 & 310 & 1594 \\
\hline Murray-Darling & 20673 & 343 & 987 & 22003 & 2061 & 34 & 98 & 2193 \\
\hline La Plata & 17127 & 73 & 1070 & 18271 & 2039 & 9 & 127 & 2175 \\
\hline Amur & 8726 & 3136 & 2355 & 14216 & 985 & 354 & 266 & 1604 \\
\hline Dnieper & 13219 & 68 & 813 & 14100 & 1732 & 9 & 107 & 1847 \\
\hline Columbia & 7238 & 1877 & 1122 & 10236 & 1852 & 480 & 287 & 2620 \\
\hline Oral & 9338 & 94 & 192 & 9624 & 2542 & 26 & 52 & 2620 \\
\hline World & 760301 & 203744 & 123533 & 1087578 & 1279 & 343 & 208 & 1830 \\
\hline
\end{tabular}

Table 3. The global water footprint of wheat production in rain-fed and irrigated lands (1996-2005).

\begin{tabular}{lrrrrrrrrr}
\hline Farming system & $\begin{array}{r}\text { Yield } \\
\text { (ton/ha) }\end{array}$ & \multicolumn{4}{c}{$\begin{array}{c}\text { Total water footprint of production } \\
\left(\mathrm{Gm}^{3} / \mathrm{yr}\right)\end{array}$} & \multicolumn{4}{c}{$\begin{array}{c}\text { Water footprint per ton of wheat } \\
\left(\mathrm{m}^{3} / \text { ton }\right)\end{array}$} \\
\cline { 2 - 10 } & & Green & Blue & Grey & Total & Green & Blue & Grey & Total \\
\hline Rain-fed & 2.5 & 611 & 0 & 66 & 676 & 1629 & 0 & 175 & 1805 \\
Irrigated & 3.3 & 150 & 204 & 58 & 411 & 679 & 926 & 263 & 1868 \\
World average & 2.7 & 760 & 204 & 124 & 1088 & 1279 & 343 & 208 & 1830 \\
\hline
\end{tabular}

The global average water footprint of rain-fed wheat production is $1805 \mathrm{~m}^{3} /$ ton, while in irrigated wheat production it is $1868 \mathrm{~m}^{3} /$ ton (Table 3). Obviously, the blue water footprint in rain-fed wheat production is zero. In irrigated wheat production, the blue water footprint constitutes $50 \%$ of the total water footprint. Although, on average, wheat yields are $30 \%$ higher in irrigated fields, the water footprint of wheat from irrigated lands is higher than in the case of rain-fed lands. When we consider consumptive water use (blue plus green water footprint) only, the water footprints of wheat from rainfed and irrigated land are more or less equal, as a global average. The reason is that, although yields are higher under irrigation, water consumption (evapotranspiration) is higher as well. Under rain-fed conditions, the actual evapotranspiration over the growing period is lower than the potential evapotranspiration, while under irrigated conditions there is more water available to meet crop water requirements, leading to an actual evapotranspiration that will approach or equal potential evapotranspiration.

The green, blue and grey water footprints of global wheat production put pressure on the freshwater system in different ways. Green water generally has a low opportunity cost compared to blue water. There are many river basins in the world where blue water consumption contributes to severe water scarcity and associated environmental problems, like in the Indus and Ganges basins as will be discussed below. Since wheat has relatively low economic water productivity (euro/ $\mathrm{m}^{3}$ ) compared to many other crops (Molden, 2007), one may question to which extent water should be allocated to wheat production in relatively water-scarce basins. The relatively low yields in rain-fed lands show that there is still plenty of room to raise green water productivity in most 


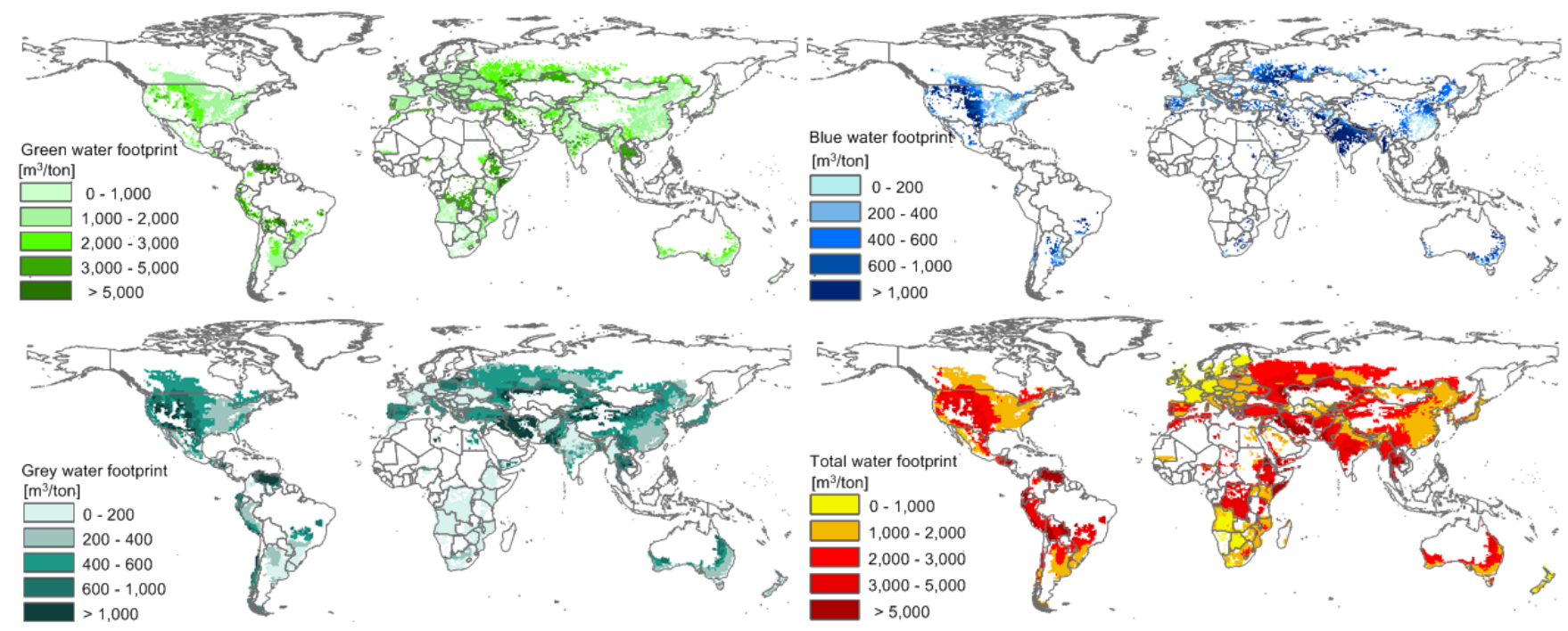

Fig. 1. The green, blue, grey and total water footprint of wheat production per ton of wheat. Period: 1996-2005.

countries, i.e. lowering the green water footprint. This is particularly relevant in policy aimed at addressing the negative externalities of blue water footprints, because increasing green water productivity and increased production from rain-fed lands will reduce the need for production from irrigated lands in water-scarce areas, and thus reduce blue water use. The grey water footprint in wheat production can generally be lowered substantially by applying fertilisers in the right amounts at the right time using appropriate application technology (precision farming), so that less fertilisers leach to groundwater or run off to surface water (Jenkinson, 2001; Norse, 2005).

\section{International virtual water flows related to trade in wheat products}

The total global virtual water flow related to trade in wheat products averaged over the period 1996-2005 was $200 \mathrm{Gm}^{3} /$ year. This means that an estimated $18 \%$ of the global water footprint was related to wheat production for export. About $87 \%$ of this amount comes from green water and only $4 \%$ from blue water and the remaining $9 \%$ is grey water. Wheat exports in the world are thus basically from rain-fed agriculture. The world's largest 26 wheat producers, which account for about $90 \%$ of global wheat production (Table 1), were responsible for about $94 \%$ of the global virtual water export. The USA, Canada and Australia alone were responsible for about $55 \%$ of the total virtual water export. China, which is the top wheat producer accounting for $17.4 \%$ of the global wheat production, was a net virtual water importer. India and the USA were the largest exporters of blue water, accounting for about $62 \%$ of the total blue water export. A very small fraction (4\%) of the total blue water consumption in wheat production was traded internationally. Surprisingly, some water-scarce regions in the world, relying on irrigation, show a net export of blue water virtually embedded in wheat. Saudi Arabia had a net blue virtual water export of $21 \mathrm{Mm}^{3} / \mathrm{yr}$ and Iraq exported a net volume of blue water of $6 \mathrm{Mm}^{3} / \mathrm{yr}$. The largest grey water exporters were the USA, Canada, Australia and Germany. Data per country are shown in Table 4 for the largest virtual water exporters and importers, respectively. The largest net virtual water flows related to international wheat trade are shown in Fig. 2.

The global water saving associated with the international trade in wheat products adds up to $65 \mathrm{Gm}^{3} / \mathrm{yr}$ (39\% green, $48 \%$ blue, and $13 \%$ grey). Import of wheat and wheat products by Algeria, Iran, Morocco and Venezuela from Canada, France, the USA and Australia resulted in the largest global water savings. Figure 3 illustrates the concept of global water saving through an example of the trade in durum wheat from France to Morocco.

\section{The water footprint of wheat from the consumption perspective}

The global water footprint related to the consumption of wheat products was estimated at $1088 \mathrm{Gm}^{3} / \mathrm{yr}$, which is $177 \mathrm{~m}^{3} / \mathrm{yr}$ per person on average (70\% green, $19 \%$ blue, and $11 \%$ grey). About $82 \%$ of the total water footprint related to consumption was from domestic production while the remaining $18 \%$ was external water footprint (Fig. 4). In terms of water footprint per capita, Kazakhstan has the largest water footprint, with $1156 \mathrm{~m}^{3} / \mathrm{cap} / \mathrm{yr}$, followed by Australia and Iran with 1082 and $716 \mathrm{~m}^{3} / \mathrm{cap} / \mathrm{yr}$, respectively. Data per country are shown in Table 5 for the major wheat consuming countries and in Fig. 5 all countries of the world. When 


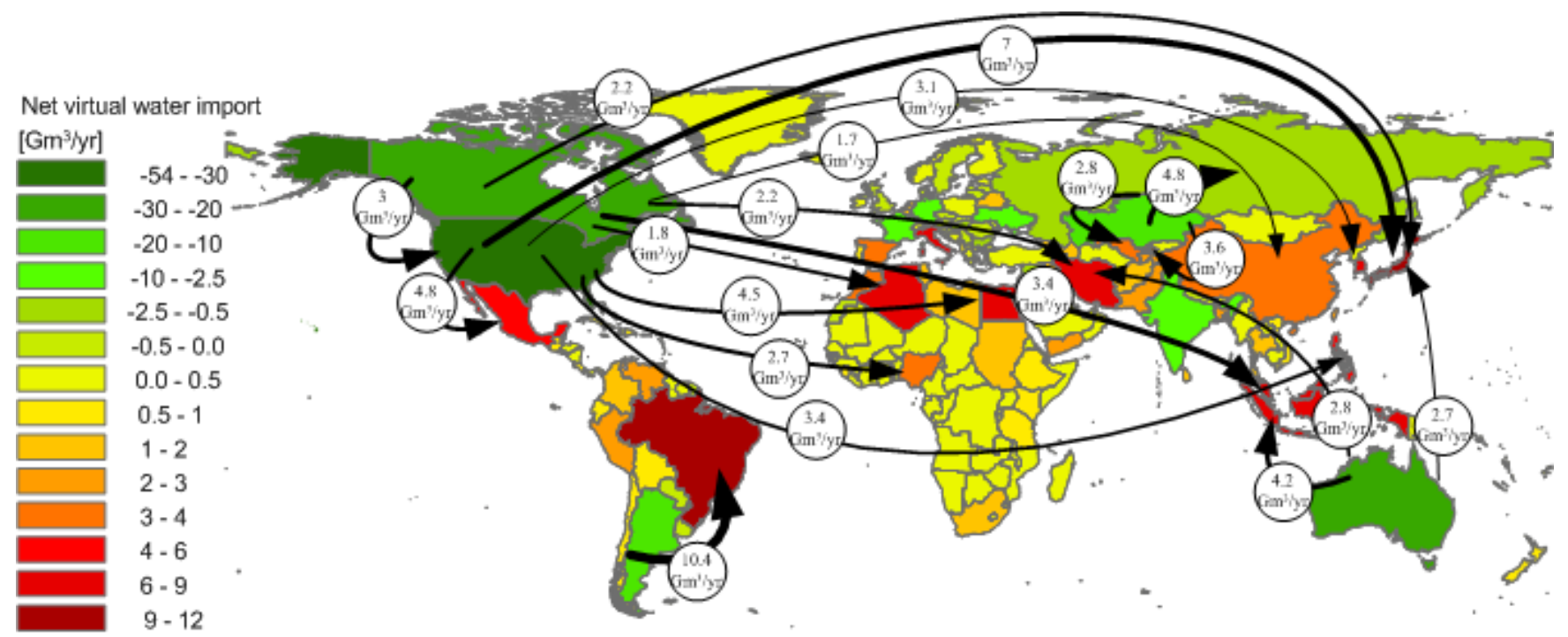

Fig. 2. National virtual water balances and net virtual water flows related to trade in wheat products in the period 1996-2005. Only the largest net flows $\left(>2 \mathrm{Gm}^{3} / \mathrm{yr}\right)$ are shown.

\section{France}

Water footprint, $\mathrm{WF}_{e}=591 \mathrm{~m}^{3} / \mathrm{ton}$

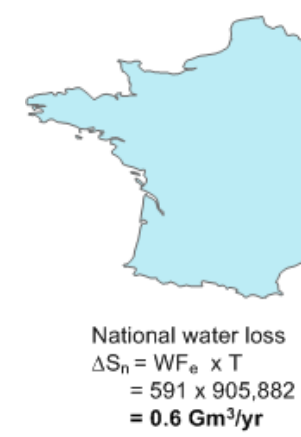

Morocco

Water footprint,$W F_{i}=5710 \mathrm{~m}^{3} /$ ton

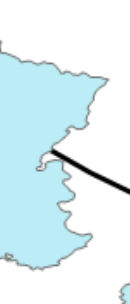

$\xi$

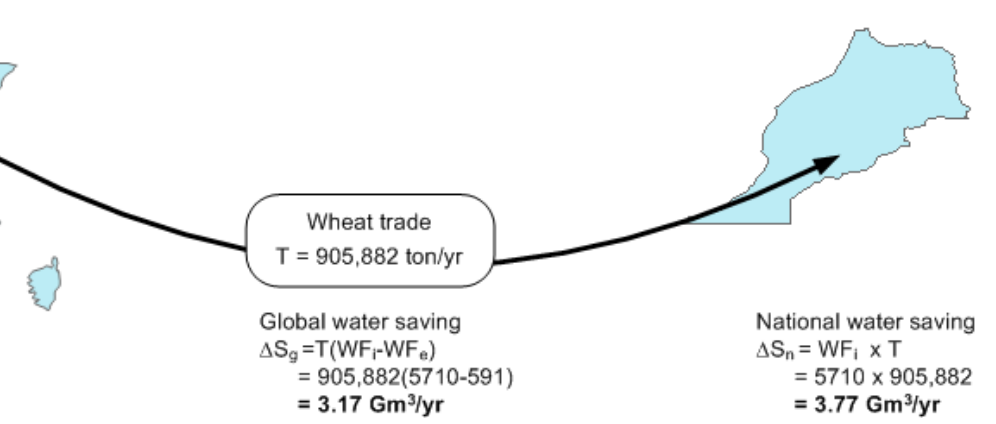

Fig. 3. Global water saving through the trade in durum wheat from France to Morocco. Period: 1996-2005.

the water footprint of wheat consumption per capita is relatively high in a country, this can be explained by either one or a combination of two factors: (i) the wheat consumption in the country is relatively high; (ii) the wheat consumed has a high water footprint per $\mathrm{kg}$ of wheat. As one can see in Table 5, in the case of Kazakhstan and Iran, both factors play a role. In the case of Australia, the relatively high water footprint related to wheat consumption can be mostly explained by the high wheat consumption per capita alone. Germany has a large wheat consumption per capita - more than twice the world average - so that one would expect that the associated water footprint would be high as well, but this is not the case because, on average, the wheat consumed in Germany has a low water footprint per $\mathrm{kg}(43 \%$ of the global average).

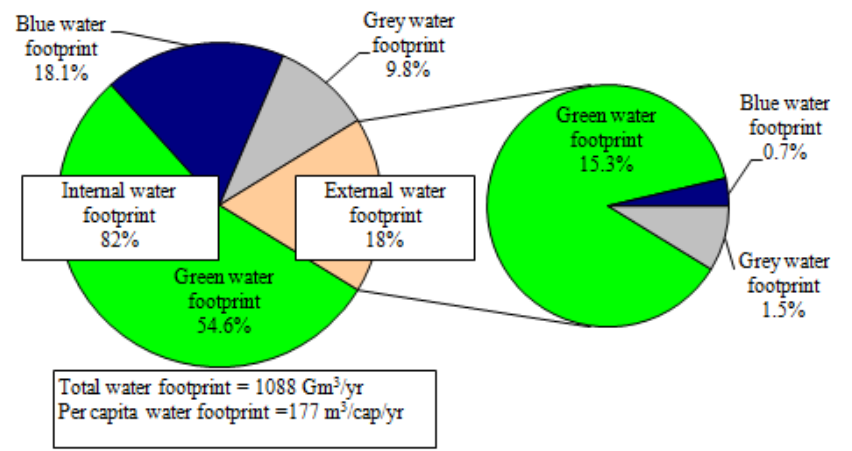

Fig. 4. Global water footprint related the consumption of wheat products. Period: 1996-2005. 
Table 4. Gross virtual water export and import related to the international trade of wheat products in the period 1996-2005.

\begin{tabular}{|c|c|c|c|c|c|c|c|c|c|}
\hline \multicolumn{4}{|c|}{$\begin{array}{l}\text { Largest virtual water exporters } \\
\qquad\left(\mathrm{Mm}^{3} / \mathrm{yr}\right)\end{array}$} & \multicolumn{6}{|c|}{$\begin{array}{l}\text { Largest virtual water importers } \\
\qquad\left(\mathrm{Mm}^{3} / \mathrm{yr}\right)\end{array}$} \\
\hline & Green & Blue & Grey & Total & & Green & Blue & Grey & Total \\
\hline USA & 48603 & 2389 & 5959 & 56952 & Brazil & 11415 & 88 & 801 & 12304 \\
\hline Canada & 24144 & 85 & 3625 & 27854 & Japan & 10393 & 320 & 1147 & 11860 \\
\hline Australia & 24396 & 201 & 1244 & 25841 & Italy & 7345 & 174 & 760 & 8279 \\
\hline Argentina & 15973 & 100 & 987 & 17060 & Egypt & 6838 & 274 & 633 & 7745 \\
\hline Kazakhstan & 16490 & 118 & 0 & 16608 & Korea, Rep & 6511 & 398 & 685 & 7594 \\
\hline France & 9347 & 21 & 89 & 9457 & Indonesia & 6512 & 364 & 577 & 7453 \\
\hline Russian Fed & 7569 & 100 & 285 & 7954 & Iran & 6105 & 60 & 504 & 6670 \\
\hline Ukraine & 4587 & 50 & 200 & 4837 & Malaysia & 5616 & 185 & 636 & 6437 \\
\hline Germany & 3537 & 0 & 1090 & 4626 & Algeria & 5330 & 323 & 696 & 6350 \\
\hline India & 1266 & 2338 & 589 & 4193 & Mexico & 5155 & 205 & 660 & 6020 \\
\hline Turkey & 2208 & 139 & 208 & 2555 & Russian Fed & 5334 & 69 & 92 & 5495 \\
\hline UK & 1189 & 0 & 441 & 1630 & Philippines & 3923 & 426 & 538 & 4887 \\
\hline Spain & 1242 & 42 & 249 & 1534 & Spain & 4161 & 80 & 493 & 4734 \\
\hline Hungary & 1035 & 2 & 352 & 1389 & China & 4087 & 98 & 453 & 4638 \\
\hline Others & 13107 & 2202 & 2488 & 17797 & Others & 85967 & 4725 & 9131 & 99823 \\
\hline Global flow & 174693 & 7789 & 17807 & 200289 & Global flow & 174693 & 7789 & 17807 & 200289 \\
\hline
\end{tabular}

Table 5. Water footprint of wheat consumption for the major wheat consuming countries (1996-2005).

\begin{tabular}{|c|c|c|c|c|c|c|c|c|c|c|c|}
\hline \multirow[t]{2}{*}{ Countries } & \multicolumn{3}{|c|}{$\begin{array}{l}\text { Internal water footprint } \\
\qquad\left(\mathrm{Mm}^{3} / \mathrm{yr}\right)\end{array}$} & \multicolumn{3}{|c|}{$\begin{array}{l}\text { External water footprint } \\
\qquad\left(\mathrm{Mm}^{3} / \mathrm{yr}\right)\end{array}$} & \multicolumn{2}{|c|}{ Water footprint } & \multirow{2}{*}{$\begin{array}{r}\text { WF per capita } \\
\text { Fraction of } \\
\text { world average }\end{array}$} & \multirow{2}{*}{$\begin{array}{r}\text { Wheat consumption } \\
\text { per capita } \\
\text { Fraction of } \\
\text { world average }\end{array}$} & \multirow{2}{*}{$\begin{array}{r}\text { WF of whea } \\
\text { products } \\
\text { Fraction o } \\
\text { world average }\end{array}$} \\
\hline & Green & Blue & Grey & Green & Blue & Grey & $\begin{array}{l}\text { Total WF } \\
\left(\mathrm{Mm}^{3} / \mathrm{yr}\right)\end{array}$ & $\begin{array}{r}\text { WF per capita } \\
\left(\mathrm{m}^{3} / \mathrm{yr}\right)\end{array}$ & & & \\
\hline China & 82990 & 47091 & 31442 & 4064 & 97 & 450 & 166134 & 133 & 0.75 & 0.86 & 0.88 \\
\hline India & 42786 & 78997 & 19903 & 931 & 17 & 64 & 142699 & 135 & 0.76 & 0.66 & 1.15 \\
\hline Russia & 83967 & 1112 & 3152 & 4915 & 63 & 85 & 93295 & 635 & 3.59 & 2.67 & 1.33 \\
\hline USA & 64508 & 3124 & 7941 & 1612 & 15 & 244 & 77444 & 270 & 1.53 & 1.32 & 1.17 \\
\hline Pakistan & 11900 & 27218 & 7856 & 2752 & 90 & 259 & 50075 & 345 & 1.95 & 1.42 & 1.37 \\
\hline Iran & 26693 & 10937 & 3208 & 6104 & 60 & 504 & 47505 & 716 & 4.04 & 2.32 & 1.74 \\
\hline Turkey & 38810 & 2434 & 3659 & 2238 & 54 & 181 & 47376 & 691 & 3.90 & 2.98 & 1.30 \\
\hline Ukraine & 21905 & 239 & 955 & 1021 & 12 & 30 & 24163 & 496 & 2.80 & 2.78 & 1.01 \\
\hline Australia & 19671 & 162 & 1005 & 8 & 1 & 3 & 20851 & 1082 & 6.11 & 5.47 & 1.16 \\
\hline Brazil & 6901 & 3 & 469 & 11224 & 88 & 788 & 19472 & 111 & 0.63 & 0.58 & 1.08 \\
\hline Egypt & 1409 & 5924 & 2692 & 6837 & 274 & 633 & 17768 & 264 & 1.49 & 1.62 & 0.92 \\
\hline Kazakhstan & 17312 & 124 & 1 & 83 & 1 & 7 & 17529 & 1156 & 6.53 & 3.92 & 1.85 \\
\hline Italy & 8274 & 114 & 1284 & 6837 & 165 & 697 & 17372 & 300 & 1.69 & 2.35 & 0.70 \\
\hline Poland & 9687 & 4 & 4478 & 572 & 7 & 94 & 14841 & 386 & 2.18 & 2.48 & 0.87 \\
\hline Morocco & 9923 & 877 & 383 & 3230 & 68 & 306 & 14786 & 505 & 2.85 & 2.21 & 1.29 \\
\hline Germany & 9459 & 0 & 2868 & 810 & 13 & 120 & 13270 & 161 & 0.91 & 2.07 & 0.43 \\
\hline World & 593599 & 196690 & 106972 & 166703 & 7147 & 16586 & 1087696 & 177 & & & \\
\hline
\end{tabular}

The countries with the largest external water footprint related to wheat consumption were Brazil, Japan, Egypt, Italy, the Republic of Korea and Iran. Together, these countries account for about $28 \%$ of the total external water footprint. Japan's water footprint related to wheat consumption lies outside the country for about $93 \%$. In Italy, with an average wheat consumption of $150 \mathrm{~kg} / \mathrm{yr}$ per person, more than two times the word average, this was about 44\%. Most African, South-East Asian, Caribbean and Central American countries strongly rely on external water resources for their wheat consumption as shown in Fig. 6. 


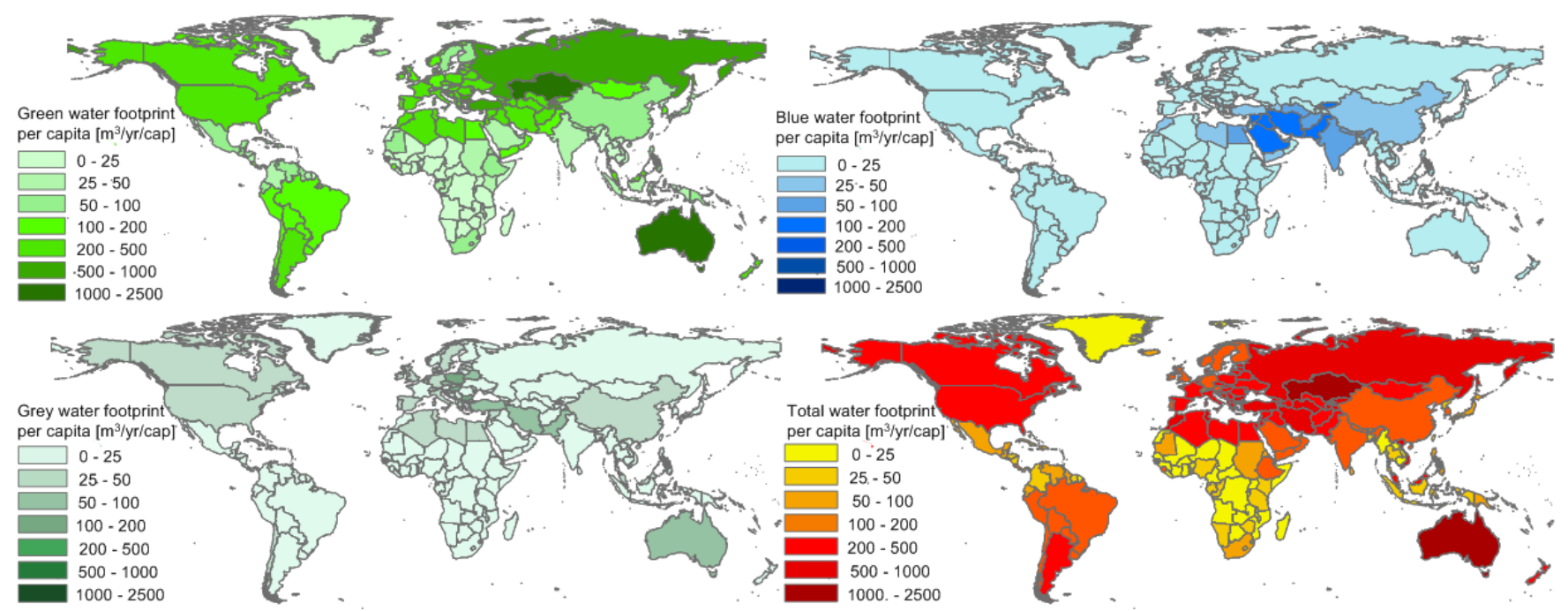

Fig. 5. Water footprint per capita related to consumption of wheat products in the period 1996-2005.

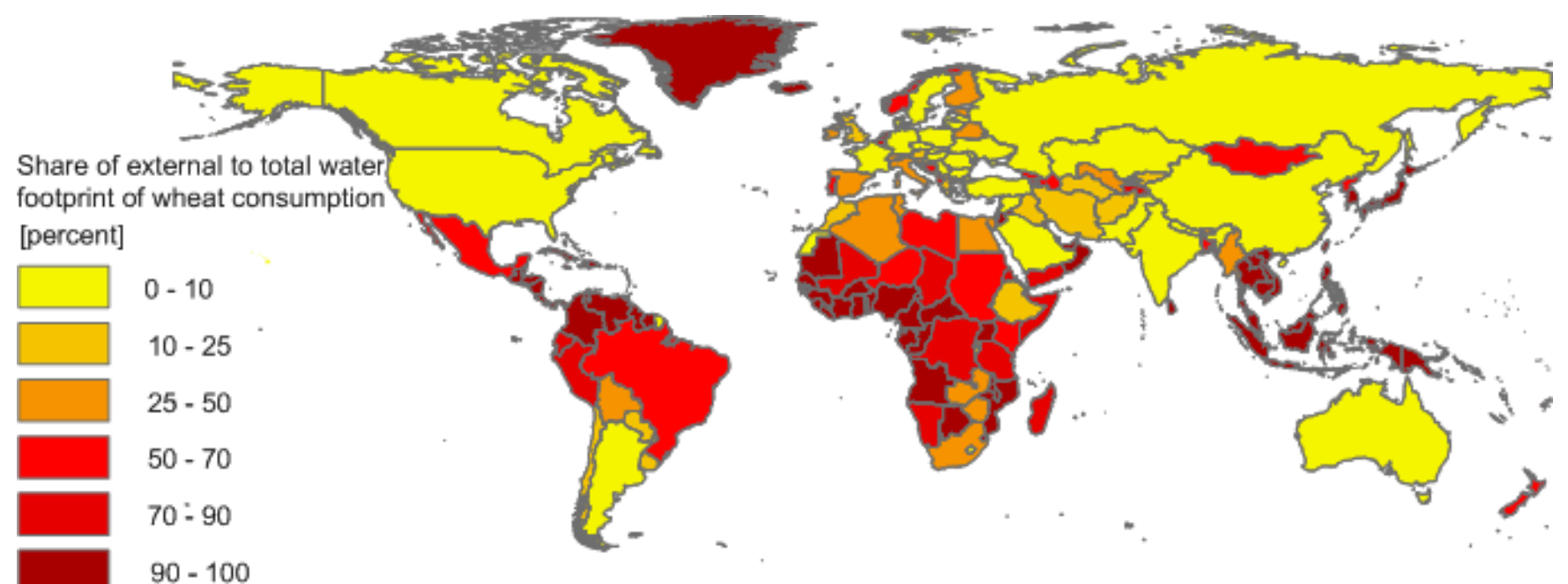

Fig. 6. The extent to which countries rely on external water resources for their wheat consumption. Period: 1996-2005.

\section{Case studies}

\subsection{The water footprint of wheat production in the Ogallala area (USA)}

The Ogallala Aquifer, also known as the High Plains Aquifer, is a regional aquifer system located beneath the Great Plains in the United States in portions of the eight states of South Dakota, Nebraska, Wyoming, Colorado, Kansas, Oklahoma, New Mexico, and Texas. It covers an area of approximately $451000 \mathrm{~km}^{2}$, making it the largest area of irrigationsustained cropland in the world (Peterson and Bernardo, 2003). Most of the aquifer underlies parts of three states: Nebraska has $65 \%$ of the aquifer's volume, Texas $12 \%$ and Kansas 10\% (Peck, 2007). About 27\% of the irrigated land in the United States overlies this aquifer system, which yields about $30 \%$ of the nation's ground water used for irrigation (Dennehy, 2000).

Water from the Ogallala Aquifer is the principal source of supply for irrigated agriculture. In 1995, the Ogallala Aquifer contributed about $81 \%$ of the water supply in the Ogallala area while the remainder was withdrawn from rivers and streams, most of it from the Platte River in Nebraska. Outside of the Platte River Valley, $92 \%$ of water used in the Ogallala area is supplied by ground water (Dennehy, 2000). Since the beginning of extensive irrigation using ground water, the water level of the aquifer has dropped by 3 to $15 \mathrm{~m}$ in most part of the aquifer (McGuire, 2007).

Within the Ogallala area, Kansas takes the largest share in wheat production (51\%), followed by Texas and Nebraska 
Table 6. Water footprint of wheat production and virtual water export from the Ogallala area (1996-2005).

\begin{tabular}{lcccccccc}
\hline $\begin{array}{l}\text { States in the } \\
\text { Ogallala area }\end{array}$ & \multicolumn{3}{c}{$\begin{array}{c}\text { Water footprint related to wheat production } \\
\left(\mathrm{Mm}^{3} / \mathrm{yr}\right)\end{array}$} & \multicolumn{3}{c}{$\begin{array}{c}\text { Virtual water export related to export of } \\
\text { wheat products }\left(\mathrm{Mm}^{3} / \mathrm{yr}\right)\end{array}$} \\
\cline { 2 - 9 } & Green & Blue & Grey & Total & Green & Blue & Grey & Total \\
\hline Kansas & 9136 & 368 & 1077 & 10581 & 8914 & 359 & 1051 & 10323 \\
Texas & 1981 & 417 & 301 & 2699 & 1933 & 407 & 294 & 2633 \\
Nebraska & 2952 & 78 & 345 & 3375 & 2880 & 76 & 337 & 3293 \\
Colorado & 2108 & 67 & 281 & 2456 & 2057 & 66 & 274 & 2397 \\
Oklahoma & 693 & 26 & 91 & 809 & 676 & 25 & 88 & 789 \\
New Mexico & 317 & 94 & 45 & 455 & 309 & 91 & 44 & 444 \\
South Dakota & 211 & 0 & 24 & 235 & 206 & 0 & 23 & 229 \\
Wyoming & 299 & 6 & 34 & 338 & 291 & 6 & 33 & 330 \\
Ogallala area total & 17696 & 1056 & 2196 & 20949 & 17266 & 1031 & 2143 & 20439 \\
\hline
\end{tabular}

a Values in the table refer to the part of the states within the Ogallala area only.

(16\% and $15 \%$, respectively). In Kansas, $84 \%$ of the wheat production comes from rain-fed areas. In Nebraska, this is $86 \%$ and in Texas $47 \%$. The Ogallala area accounts for about $14 \%$ of the total wheat production in the USA. Our study shows that $16 \%$ of the total water footprint of wheat production in the country lies in the Ogallala area. About $19 \%$ of the blue water footprint of wheat production in the USA is in the Ogallala area (Table 6). The total water footprint in the Ogallala area was $21 \mathrm{Gm}^{3} / \mathrm{yr}(85 \%$ green, $5 \%$ blue, and $10 \%$ grey).

Texas takes the largest share $(39 \%)$ in the blue water footprint of wheat production in the Ogallala area, followed by Kansas (35\%). There is a considerable variation in the blue water footprint per ton of wheat within the Ogallala area. Besides, the blue water footprint per ton of wheat in the Ogallala area is relatively high if compared to the average in the USA.

In the period 1996-2005, the virtual water export related to export of wheat products from the USA was $57 \mathrm{Gm}^{3} / \mathrm{yr}$. About $98 \%\left(55.6 \mathrm{Gm}^{3} / \mathrm{yr}\right)$ of the virtual water export comes from domestic water resources and the remaining $2 \%\left(1.4 \mathrm{Gm}^{3} / \mathrm{yr}\right)$ is from re-export of imported virtual water related to import of wheat products. Taking the per capita wheat consumption in the USA of about $88 \mathrm{~kg} / \mathrm{yr}$ (FAO, 2008) and a population in the Ogallala area of 2.4 million (CIESIN and CIAT, 2005) we can find that only $2 \%$ of the wheat produced is consumed within the Ogallala area and the surplus (about 98\%) is exported out of the Ogallala area to other areas in the USA or exported to other countries. This surplus of wheat constitutes $33 \%$ of the domestic wheat export from the USA (Table 6). Figure 7 shows the major foreign destinations of wheat-related virtual water exports from the area of the Ogallala Aquifer.

The water footprint related to wheat production for export is putting pressure on the water resources of the Ogallala Aquifer (McGuire, 2007). Visualising the hidden link between the wheat consumer elsewhere and the impact of wheat production on the water resources of the Ogallala Aquifer is quite relevant in policy aimed at internalizing the negative externalities of wheat production and passing such externalities cost to consumers elsewhere.

\subsection{The water footprint of wheat production in the Ganges and Indus river basins}

The Ganges river basin, which is part of the composite Ganges-Brahmaputra-Meghna river basin, is one of most densely populated river basins in the world. It covers about 1 million $\mathrm{km}^{2}$ (Gleick, 1993). The Indus river basin, which extends over four countries (China, India, Pakistan and Afghanistan), is also a highly populated river basin. The area of the Indus basin is a bit smaller than the Ganges basin but covers nearly 1 million $\mathrm{km}^{2}$ as well (Gleick, 1993).

The two river basins together account for about $90 \%$ of the wheat production in India and Pakistan in the period 19962005. Almost all wheat production (98\%) in Pakistan comes from the Indus river basin. About $89 \%$ of India's wheat is produced in the Ganges (62\%) and the Indus basin $(27 \%)$. About $87 \%$ of the total water footprint related to wheat production in India and Pakistan lies in these two river basins. The total water footprint of wheat production in the Indian part of the Ganges basin is $92 \mathrm{Gm}^{3} / \mathrm{yr}$ ( $32 \%$ green, $54 \%$ blue, $14 \%$ grey). The total water footprint of wheat production in the Pakistani part of the Indus basin is $48 \mathrm{Gm}^{3} / \mathrm{yr}(25 \%$ green, $58 \%$ blue, $17 \%$ grey).

In the period 1996-2005, India and Pakistan together had a virtual water export related to wheat export of $5.1 \mathrm{Gm}^{3} / \mathrm{yr}$ ( $29 \%$ green water, $56 \%$ blue, $15 \%$ grey), which is a small fraction $(3 \%)$ of the total water footprint of wheat production in these two countries. About $55 \%$ of this total virtual water export comes from the Ganges basin and $45 \%$ from the Indus basin. The blue water export to other countries from the Ganges and Indus river basins was $1304 \mathrm{Mm}^{3} / \mathrm{yr}$ and $1077 \mathrm{Mm}^{3} / \mathrm{yr}$, respectively. 


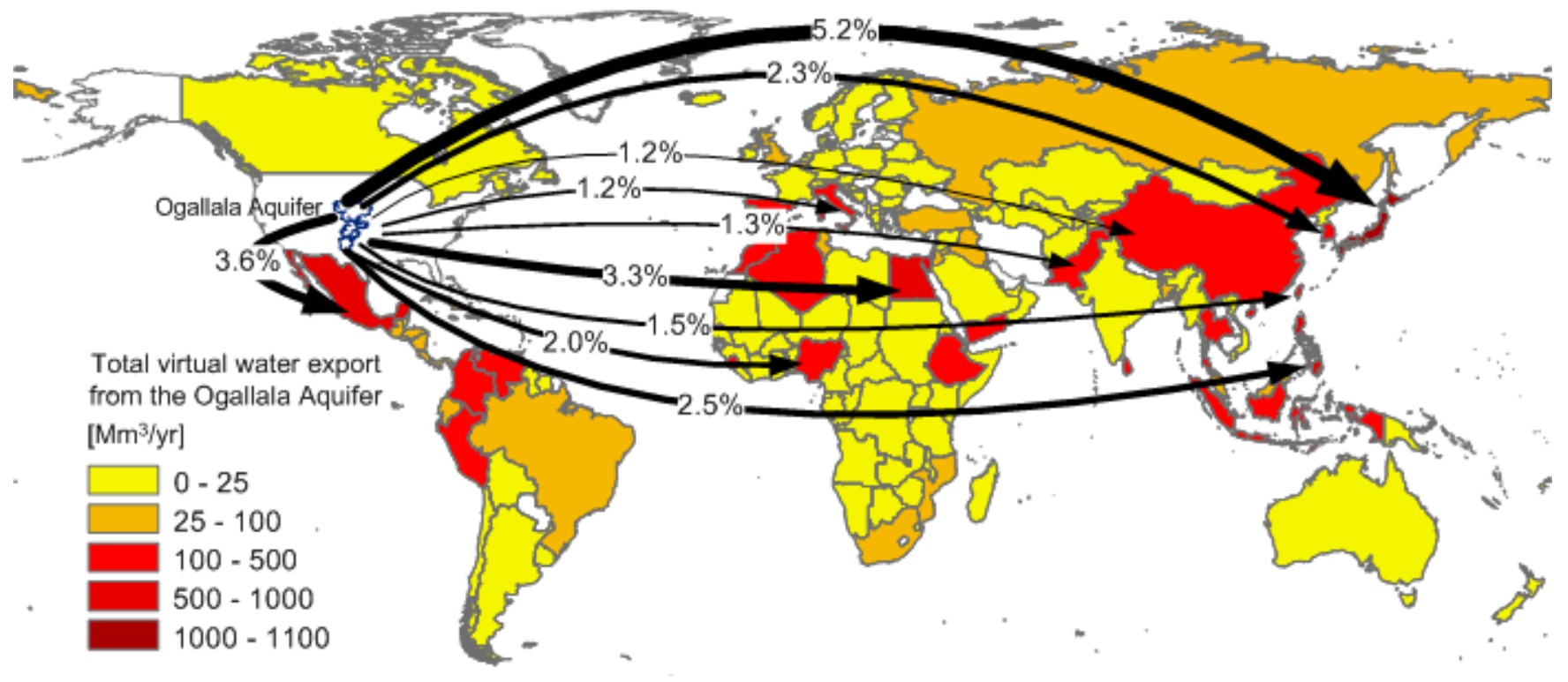

Fig. 7. Major destinations of wheat-related virtual water exports from the Ogallala area in the USA (1996-2005). About 58\% of the total water footprint of wheat production in the area is for wheat consumption in the USA and $42 \%$ is for export to other nations. Only the largest exports $(>1 \%)$ are shown.

Based on the water withdrawal-to-availability ratio, which is an indicator of water stress (Alcamo et al., 2003a, 2007; Cosgrove and Rijsberman, 2000), most parts of Pakistan and India are highly water stressed (Alcamo et al., 2003b). Both the Ganges and Indus river basins are under severe water stress, in particular the Indus river basin. About $97 \%$ of the water footprint related to wheat production in the two basins is for domestic consumption within the two countries. Since the two basins are the wheat baskets of the two countries, there are substantial virtual water transfers from the Ganges and Indus basins to other areas within India and Pakistan. By looking at the virtual flows both within the country and to other countries, it is possible to link the impacts of wheat consumption in other places to the water stress in the Ganges and Indus basins. For the case of India, Kampman et al. (2008) have shown that the states which lie within the Indus and Ganges river basins, such as Punjab, Uttar Pradesh and Haryana are the largest inter-state virtual water exporters within India. The highly subsidized irrigation water in these regions has led to an intensive exploitation of the available water resources in these areas compared to other, more waterabundant regions of India. In order to provide incentives for water protection, negative externalities such as water overexploitation and pollution, and also scarcity rents should be included in the price of the crop. Both basins have a relatively high water productivity, which is shown by a smaller water footprint per ton of wheat, compared to other wheat producing areas in the two countries (Fig. 8). Since wheat is a low-value crop, one may question whether water allocation to wheat production for export in states such as Punjab,
Uttar Pradesh and Haryana is worth the cost. A major destination of wheat exports from India's parts of the Indus and Ganges basins is East India, to states like Bihar. Major foreign destinations of India's virtual water export related to export of wheat products are Bangladesh (22\%), Indonesia $(11 \%)$, Philippines (10\%) and Yemen (10\%). Pakistan's export mainly goes to Afghanistan (56\%) and Kenya (11\%).

\subsection{The external water footprint of wheat consumption in Italy and Japan}

In the previous two sections we have looked into the water footprint of wheat production in specific areas of the world and analysed how this water footprints could be linked to consumers elsewhere. In this section we will do the reverse: we will consider the wheat consumers in two selected countries - Italy and Japan - and trace where their water footprint lies.

Italy's water footprint related to the consumption of wheat products for the period $1996-2005$ was $17.4 \mathrm{Gm}^{3} / \mathrm{yr}$. More than half $(56 \%)$ of Italy's water footprint is pressing on domestic water systems. The rest of the water footprint of Italian wheat consumption lies in other countries, mainly the USA (20\%), France (19\%), Canada (11\%) and Russia (10\%). The water footprint of Italy's wheat consumers in the USA lies in different regions of that country, among others in the Ogallala area as earlier shown in Fig. 7. Italy also imports virtual water from the water-scarce countries of the Middle East, such as Syria $\left(58 \mathrm{Mm}^{3} / \mathrm{yr}\right)$ and $\operatorname{Iraq}\left(36 \mathrm{Mm}^{3} / \mathrm{yr}\right)$.

About $93 \%$ of the water footprint of wheat consumption in Japan lies in other countries, mainly in the USA (59\%), 

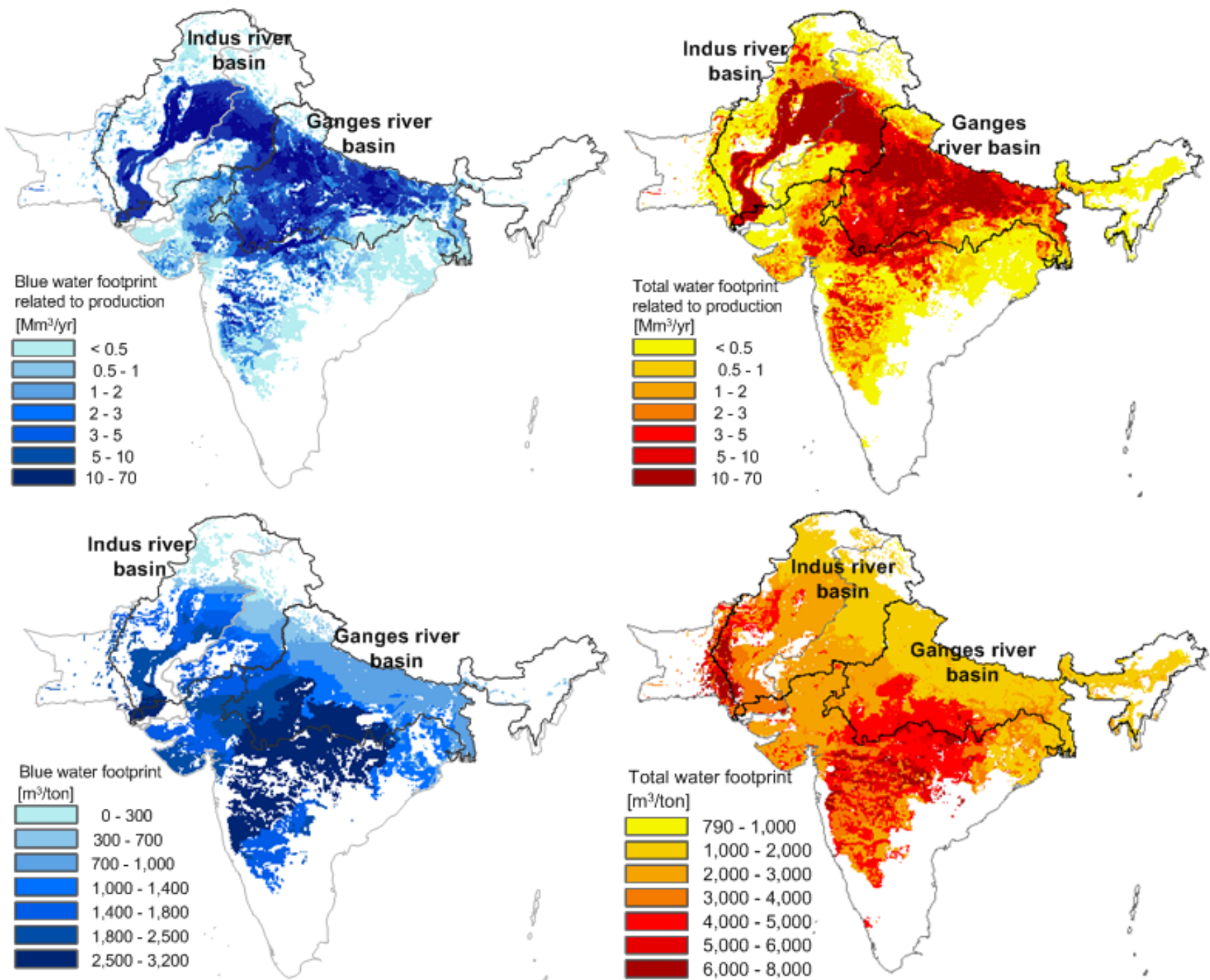

Fig. 8. The total and blue water footprint related to wheat production in India and Pakistan, both expressed as a total (Mm $\left.{ }^{3} / \mathrm{yr}\right)$ and per ton of wheat ( $\mathrm{m}^{3} /$ ton). Period: $1996-2005$.

Australia (22\%) and Canada (19\%). About 87\% of Japan's external water footprint is from green water. Japan's wheatrelated water footprint in the USA partly presses on the water resources of the Ogallala area as shown in Fig. 7. The water footprint in Australia largely lies in Southern Australia where most of the wheat is produced and water scarcity is high.

\section{Discussion}

The results of the current study can be compared to results from earlier studies as shown in Table 7. The global average water footprint of wheat in our study comes to $1622 \mathrm{~m}^{3} /$ ton (excluding grey water), while earlier studies gave estimates of $1334 \mathrm{~m}^{3} /$ ton (Chapagain and Hoekstra, 2004), $1253 \mathrm{~m}^{3} /$ ton (Liu et al., 2007) and $1469 \mathrm{~m}^{3} /$ ton
(Siebert and Döll, 2010). A variety of factors differ in the various studies, so that it is difficult to identify the main reason for the different results. The model results with respect to the wheat water footprint per ton can also be compared for a number of specific locations to the inverse of the measured crop water productivity values as collected by Zwart and Bastiaanssen (2004). The comparison shows that out of 28 measured sites, for 17 sites (61\% of the time) the simulated water footprint lies within the range of measured values.

The model results with respect to the total global water footprint of wheat production can be compared to three previous global wheat studies. The study by Chapagain and Hoekstra (2004) did not take a grid-based approach and also did not make the green-blue distinction, unlike the current study and the studies by Siebert and Döll (2010) and Liu et 
Table 7. Comparison between the results from the current study with the results from previous studies.

\begin{tabular}{|c|c|c|c|c|c|}
\hline Study & Period & $\begin{array}{l}\text { Global } \\
\text { average } \\
\text { water } \\
\text { footprint of } \\
\text { wheat }\end{array}$ & $\begin{array}{l}\text { Global water } \\
\text { footprint } \\
\text { related to } \\
\text { wheat } \\
\text { production }\end{array}$ & $\begin{array}{l}\text { International } \\
\text { virtual water } \\
\text { flows related } \\
\text { to wheat } \\
\text { trade }\end{array}$ & $\begin{array}{l}\text { Global water } \\
\text { saving due } \\
\text { to wheat } \\
\text { trade }\end{array}$ \\
\hline & & $\mathrm{m}^{3} / \mathrm{ton}$ & $\mathrm{Gm}^{3} / \mathrm{yr}$ & $\mathrm{Gm}^{3} / \mathrm{yr}$ & $\mathrm{Gm}^{3} / \mathrm{yr}$ \\
\hline Hoekstra and Hung $(2002,2005)$ & 1995-1999 & - & - & 210 & - \\
\hline $\begin{array}{l}\text { Chapagain and Hoekstra (2004), } \\
\text { Chapagain et al. (2006a), } \\
\text { Hoekstra and Chapagain (2008) }\end{array}$ & $1997-2001$ & 1334 & 793 & 114 & 103 \\
\hline Oki and Kanae (2004) & 2000 & - & - & 271 & 193 \\
\hline Yang et al. (2006) & 1997-2001 & - & - & 188 & 130 \\
\hline Liu et al. $(2007,2009)$ & 1998-2002 & 1253 & 688 & 159 & 77 \\
\hline Siebert and Döll (2010) & 1998-2002 & 1469 & 858 & - & - \\
\hline Hanasaki et al. (2010) & 2000 & - & - & 122 & - \\
\hline Current study, green and blue only & 1996-2005 & 1622 & 964 & 182 & 57 \\
\hline Current study incl. grey water ${ }^{a}$ & 1996-2005 & 1830 & 1088 & 200 & 65 \\
\hline
\end{tabular}

a None of the previous studies included grey water, so these figures are for information only, not for comparison.

al. (2009), therefore we will compare here only with the latter two. When we compare the computed green and blue water footprints to the computation by Siebert and Döll (2010), we find that their estimate of the total water footprint of global wheat production is $11 \%$ lower, which is completely due to their lower estimate of the green water footprint component. The estimate of the total water footprint by Liu et al. (2009) is $29 \%$ lower than our estimate, again due to the difference in the estimate of the green component. The relatively low value presented by Liu et al. (2009) is not a surprise given the fact that their estimate is based on the GEPIC model, which has been shown to give low estimates of evapotranspiration compared to other models (Hoff et al., 2010). Our estimate of the total green water footprint in global wheat production is $760 \mathrm{Gm}^{3} / \mathrm{yr}$ (period 1996-2005), whereas Siebert and Döll (2010) give an estimation of $650 \mathrm{Gm}^{3} / \mathrm{yr}$ (period 1998-2002) and Liu et al. (2009) $540 \mathrm{Gm}^{3} / \mathrm{yr}(1998-2002)$. Our estimate of the total blue water footprint in global wheat production is $204 \mathrm{Gm}^{3} / \mathrm{yr}$, whereas Siebert and Döll (2010) give an estimation of $208 \mathrm{Gm}^{3} / \mathrm{yr}$ and Liu et al. (2009) $150 \mathrm{Gm}^{3} / \mathrm{yr}$.

Liu et al. (2009) use another water balance model than applied in the current study. As a basis, they use the EPIC model (Williams et al., 1989), whereas we apply the model of Allen et al. (1998). Although both models compute the same variables, EPIC has been developed as a crop growth model, whereas the model of Allen et al. (1998) has been developed as a water balance model, which makes that the two models have a different structure and different parameters. One of the differences is the runoff model applied, which affects the soil water balance and thus soil water availability and finally the green water footprint. Besides, Liu et al. (2009) estimate water footprints $\left(\mathrm{m}^{3} /\right.$ ton) based on computed yields, whereas we use computed yields, but scale them according to FAO statistics. Siebert and Döll (2010) basically apply the same modelling approach as in the current study. Both studies have the same spatial resolution, carry out a soil water balance with a daily time step, use the same CRU TS-2.1 climate data source to generate the daily precipitation and use the same crop, soil and irrigation maps. Although there are many similarities, the studies differ in some respects. For estimating daily reference evapotranspiration data, Siebert and Döll (2010) applied the cubic splin method to generate daily climate data from the monthly data as provided in the available database. In contrast, we have used long-term monthly average reference evapotranspiration global spatial data obtained from FAO (2008b) and converted these data to daily values by polynomial interpolation. Further, Siebert and Döll (2010) have considered multicropping based on a number of assumptions and generated their own cropping calendar based on climatic data, while in our study we have neglected multi-cropping and adopted cropping calendars as provided in literature at country level. Siebert and Döll (2010) compute local yields and scale them later on, like in the current study, but scaling is done in different manner. Finally, in our study we include the grey water footprint and study international virtual water flows, which is not done by Siebert and Döll (2010).

It is difficult to make a conclusion about the accuracy or reliability of our estimates vice versa the quality of the data presented in the other two modelling studies cited. All studies depend on a large set of assumptions with respect to 
modelling structure, parameter values, datasets used and period considered. For the time being, it is probably best to conclude that the divergence in outcomes is a reflection of the uncertainties involved. It implies that all estimates - both from the current and the previous studies - should be interpreted with care. Assuming that the different study periods are comparable, the three studies together give an estimation of the total water footprint of wheat production of about $830 \mathrm{Gm}^{3} / \mathrm{yr} \pm 17 \%$. This uncertainty range is probably still a conservative estimate, because it is based on the central estimates of three different modelling studies only. Furthermore, locally, differences and uncertainty ranges can be larger.

The green water footprint estimate is sensitive to a variety of assumptions, including: (a) the daily rain pattern (b) the modelling of runoff, (l) the rooting depth, (d) the soil type, which determines the soil water holding capacity, (e) the planting and harvesting dates and thus the length of the growing period, (f) the moisture content in the soil at the moment of planting, $(\mathrm{g})$ the modelling of yield. The blue water footprint estimate depends on the same assumptions, plus it depends on data on actual irrigation. In a global study, given the limitations in global databases, it seems very difficult in this stage to reduce the uncertainties. Higher resolution maps of all input parameters and variables, based on either local measurements or remote sensing (Romaguera et al., 2010) may finally help to reduce the uncertainties in a global assessment like this one. In local studies, it will generally be less time-consuming to find better estimates for the various parameters and data involved and better be able to validate the model used for the specific local conditions, so that uncertainties can be reduced more easily.

The estimation of the grey water footprint in this study is based on a simplified approach, assuming a certain leachingrunoff fraction and a maximum acceptable concentration of nitrogen in the receiving water body. This approach gives a rough estimate; it leaves out local factors that influence the precise leaching rates, such as rainfall intensity, soil property and the amount of the already mineralized nitrogen in the upper soil layer. A possible improvement in estimating the amount of nitrogen lost through leaching would be to use more advanced models such as De Willigen (2000) regression model. This model has been used by a number of studies including FAO (Roy et al. 2003), Smaling et al. (2008) in the Brazilian soybean agriculture study, Haileslassie et al. (2007) in the nutrient flows and balance study in the central highland of Ethiopia, and Lesschen et al. (2007) in the soil nutrient balance study in Burkina Faso. Most recently, Liu et al. (2010) have shown the application of the model in a highresolution assessment of global nitrogen flows in cropland.

Estimating water footprints of crops at national level and estimating international virtual water flows based on those national estimates - as done in all previous global water footprint studies until date - hides the existing variation at subnational level in climatic conditions, water resources availability and crop yields. Therefore, the present study is an attempt to improve water footprint accounting through implementing the calculations at a grid basis, which takes into account the existing heterogeneity at grid level. Such approach has the advantage of being able to pinpoint precisely in space where the water footprint of wheat consumption is located. We have combined the water footprint assessment framework as provided in Hoekstra and Chapagain (2008) and Hoekstra et al. (2009) with a grid-based approach to estimating crop evapotranspiration as applied by for example Liu et al. (2009) and Siebert and Döll (2010).

\section{Conclusions}

The major findings of the current study are that: (i) the green water footprint related to global wheat production is about four times larger than the blue water footprint, (ii) a large amount of global water saving occurs as a result of international trade in wheat products - without trade the global wheat-related water footprint would be $6 \%$ higher than under current conditions, (iii) the high share of blue water (48\%) in the global water saving indicates that the water footprint of wheat in the largest virtual water export regions is dominated by green water while virtual water import regions depend more strongly on blue water for wheat production. The study agrees with earlier studies in the importance of green water in global wheat production and the relevance of virtual water trade in global water savings. It is observed that the costs of water consumption and pollution are not yet properly factored into the price of traded wheat, so that export countries bear the cost related to wheat consumption in the importing countries.

The study showed that the global water footprint of wheat production for the period $1996-2005$ was $1088 \mathrm{Gm}^{3} / \mathrm{yr}(70 \%$ green, $19 \%$ blue, $11 \%$ grey). Since about $18 \%$ of the global water footprint related to wheat production is for making products for export, the importance of mapping the impact of global wheat consumption on local water resources with the help of the water footprint and virtual water trade accounting framework is quite clear. Quantifying the water footprint of wheat consumption and visualizing the hidden link between wheat consumers and their associated appropriation of water resources elsewhere (in the wheat producing areas) is quite relevant. The study shows that countries such as Italy and Japan, with high external water footprints related to wheat consumption, put pressure on the water resources of their trading partners. Including a water scarcity rent and the external costs of water depletion and pollution in the price of the wheat traded is crucial in order to provide an incentive within the global economy to enhance the efficiency and sustainability of water use and allocation.

The model result was compared with measured water productivity values found in the literature and outputs of previous studies. It appears very difficult to attribute differences in estimates from the various studies to specific factors; 
also it is difficult to assess the quality of our new estimates relative to the quality of earlier estimates. Our grid-based estimates of the water footprint of wheat production are better than the earlier national estimates as provided by Chapagain and Hoekstra (2004), but it is not possible to claim that they are better than the results from similar grid-based estimates as presented by Liu et al. (2009) and Siebert and Döll (2010). The quality of input data used defines the accuracy of the model output; all studies suffer the same sorts of limitations in terms of data availability and quality and deal with that in different ways. It has been observed that the model output is sensitive for example to the soil data and crop calendar, which are parameters about which no accurate data are available. A slight change in the planting date and length of cropping has a significant impact on the crop water footprint. In future studies it would be useful to spend more effort in structurally studying the sensitivity of the model outcomes to assumptions and parameters and assessing the uncertainties in the final outcome.

Edited by: J. Liu

\section{References}

Addiscott, T. M.: Fertilizers and Nitrate Leaching, in: Agricultural Chemicals and the Environment, edited by: Hester, R. E. and Harrison, R. M., Issues in Environmental Science and Technology, No. 5, 1-26, The Royal Society of Chemistry, Cambridge, UK, 1996.

Alcamo, J., Döll, P., Henrichs, T., Kaspar, F., Lehner, B., Rösch, T., and Siebert, S.: Development and testing of the WaterGAP 2 global model of water use and availability, Hydrolog. Sci. J., 48(3), 317-337, 2003a.

Alcamo, J., Döll, P., Henrichs, T. Kaspar, F., Lehner, B., Rösch, T., and Siebert, S.: Global estimation of water withdrawals and availability under current and business as usual conditions, Hydrolog. Sci. J., 48(3), 339-348, 2003b.

Alcamo, J., Flörke, M., and Märker, M.: Future long-term changes in global water resources driven by socio-economic and climatic changes, Hydrolog. Sci. J., 52(2), 247-275, 2007.

Aldaya, M. M., Allan, J. A., and Hoekstra, A. Y.: Strategic importance of green water in international crop trade, Ecol. Econ., 69(4), 887-894, 2010.

Aldaya, M. M. and Hoekstra, A. Y.: The water needed for Italians to eat pasta and pizza, Agr. Syst., 103, 351-360, 2010.

Allan, J. A.: Virtual water - the water, food, and trade nexus: Useful concept or misleading metaphor? Water Inter., 28(1), 106-113, 2003.

Allen, R. G., Pereira, L. S., Raes, D., and Smith, M.: Crop evapotranspiration: guidelines for computing crop water requirements, FAO Drainage and Irrigation Paper 56, Food and Agriculture Organization, Rome, 1998.

Batjes, N. H.: ISRIC-WISE derived soil properties on a 5 by 5 arcminutes global grid. Report 2006/02, ISRIC - World Soil Information, Wageningen, The Netherlands (available at: www.isric. org), 2006.
Bergström, S.: The HBV-model, in: Computer models for watershed hydrology, edited by: Singh, V. P., Water Resources Publications, Highlands Ranch, Colorado, USA, 443-476, 1995.

Center for International Earth Science Information Network (CIESIN), Columbia University; and Centro Internacional de Agricultura Tropical (CIAT): Gridded Population of the World Version 3 (GPWv3): Population Density Grids, Palisades, NY: Socioeconomic Data and Applications Center (SEDAC), Columbia University, available at: http://sedac.ciesin.columbia. edu/gpw, 2005.

Chapagain, A. K. and Hoekstra, A. Y.: Water footprints of nations, Value of Water Research Report Series No. 16, UNESCO-IHE, Delft, The Netherlands, 2004.

Chapagain, A. K. and Hoekstra, A. Y.: The global component of freshwater demand and supply: An assessment of virtual water flows between nations as a result of trade in agricultural and industrial products, Water Int. 33(1), 19-32, 2008.

Chapagain, A. K., Hoekstra, A. Y., and Savenije, H. H. G.: Water saving through international trade of agricultural products, Hydrol. Earth Syst. Sci., 10, 455-468, doi:10.5194/hess-10-4552006, 2006.

Chapagain, A. K., Hoekstra, A. Y., Savenije, H. H. G., and Gautam, R.: The water footprint of cotton consumption: an assessment of the impact of worldwide consumption of cotton products on the water resources in the cotton producing countries, Ecol. Econ., 60(1), 186-203, 2006b.

Cosgrove, W. and Rijsberman, F.: World Water Vision: Making Water Everybody's Business, World Water Council, Earthscan, London, 2000.

De Fraiture, C., Cai, X., Amarasinghe, U., Rosegrant, M., and Molden, D.: Does international cereal trade save water? The impact of virtual water trade on global water use. Comprehensive Assessment Research Report, Vol. 4, International Water Management Institute, Colombo, 2004.

De Willigen, P.: An analysis of the calculation of leaching and denitrification losses as practised in the NUTMON approach, Plant Research International, Wageningen, The Netherlands, 2000.

Dennehy, K. F.: High Plains regional ground-water study: U.S. Geological Survey Fact Sheet FS-091-00, available at: http:// co.water.usgs.gov/nawqa/hpgw/factsheets/DENNEHYFS1.html, 2000.

Doorenboos, J. and Pruitt, W. O.: Crop water requirements, FAO Irrigation and Drainage Paper No. 24, FAO, Rome, Italy, 1977.

Doorenbos, J. and Kassam, A. H.: Yield response to water, FAO Drainage and Irrigation Paper 33, FAO, Rome, 1979.

Dubcovsky, J. and Dvorak, J.: Genome plasticity a key factor in the success of polyploid wheat under domestication, Science, 316(5833), 1862-1866, 2007.

Ekboir, J. (Ed.): CIMMYT 2000-2001 World wheat overview and outlook: Developing no-till packages for small-scale farmers, International Maize and Wheat Improvement Center, Mexico, 2002.

FAO: Fertilizer by crop, FAO Fertilizer and Plant Nutrition Bulletin 17, Food and Agriculture Organization, Rome, 2006.

FAO: FAOSTAT on-line database, Food and Agriculture Organization, Rome, http://faostat.fao.org, last access: 10 October 2008, 2008a. 
FAO: Global map of monthly reference evapotranspiration - 10 arc minutes. GeoNetwork: grid database, Food and Agriculture Organization, Rome, www.fao.org/geonetwork/ srv/en/resources.get?id=7416\&fname $=$ ref_evap_fao_ $10 \mathrm{~min}$. zip\&access=private, last access: 15 October $2008 \mathrm{~b}$.

FAO: FertiStat - Fertilizer use statistics. Food and Agriculture Organization, Rome, www.fao.org/ag/agl/fertistat/, last access: 10 February 2009.

Gerbens-Leenes, W., Hoekstra, A.Y., and Van der Meer, T.H.: The water footprint of bioenergy, P. Natl. Acad. Sci., 106(25), 1021910223, 2009.

Gleick, P. H. (ed.): Water in crisis: A guide to the world's fresh water resources, Oxford University Press, Oxford, UK, 1993.

Goulding, K. W. T., Poulton, P. R., Webster, C. P., and Howe, M. T.: Nitrate leaching from the Broadbalk Wheat Experiment, Rothamsted, UK, as influenced by fertilizer and manure inputs and weather, Soil Use and Manage., 16(4), 244-250, 2000.

Haileslassie, A., Priess, J. A., Veldkamp, E., and Lesschen, J. P.: Nutrient flows and balances at the field and farm scale: Exploring effects of land-use strategies and access to resources, Agric Syst., 94, 459-470, 2007.

Hanasaki, N., Inuzuka, T., Kanae, S., and Oki, T.: An estimation of global virtual water flow and sources of water withdrawal for major crops and livestock products using a global hydrological model, J. Hydrol., 384, 232-244, 2010.

Heffer, P.: Assessment of Fertilizer Use by Crop at the Global Level 2006/07-2007/08, International Fertilizer Industry Association, Paris, 2009.

Hoekstra, A. Y. (Ed.): Virtual water trade: Proceedings of the International Expert Meeting on Virtual Water Trade, Delft, The Netherlands, 12-13 December 2002, Value of Water Research Report Series No.12, UNESCO-IHE, Delft, The Netherlands, available at: www.waterfootprint.org/Reports/Report12. pdf, 2003.

Hoekstra, A. Y. and Chapagain, A. K.: Water footprints of nations: water use by people as a function of their consumption pattern, Water Resour. Manag., 21(1), 35-48, 2007.

Hoekstra, A. Y. and Chapagain, A. K.: Globalization of water: Sharing the planet's freshwater resources, Blackwell Publishing, Oxford, UK, 2008.

Hoekstra, A. Y., Chapagain, A. K., Aldaya, M. M., and Mekonnen, M. M.: Water footprint manual: State of the art 2009, Water Footprint Network, Enschede, the Netherlands, available at: www.waterfootprint.org/downloads/ WaterFootprintManual2009.pdf, 2009.

Hoekstra, A. Y. and Hung, P. Q.: Virtual water trade: A quantification of virtual water flows between nations in relation to international crop trade. Value of Water Research Report Series No. 11, UNESCO-IHE, Delft, The Netherlands, available at: www.waterfootprint.org/Reports/Report11.pdf, 2002.

Hoekstra, A. Y. and Hung, P. Q.: Globalisation of water resources: International virtual water flows in relation to crop trade, Global Environ. Chang., 15(1), 45-56, 2005.

Hoff, H., Falkenmark, M., Gerten, D., Gordon, L., Karlberg, L., and Rockström, J.: Greening the global water system, J. Hydrol., 384, 177-186, 2010

IFA: International Fertilizer Industry Association Databank, www. fertilizer.org/ifa/ifadata/results, last access: 24 September 2009.
ITC: SITA version 1996-2005 in SITC, [DVD-ROM], International Trade Centre, Geneva, 2007.

Jenkinson, D. S.: The impact of humans on the nitrogen cycle, with focus on temperate arable agriculture, Plant Soil, 228(1), 3-15, 2001

Kampman, D. A., Hoekstra, A. Y., and Krol, M. S.: The water footprint of India, Value of Water Research Report Series No. 32, UNESCO-IHE, Delft, The Netherlands, 2008.

King, J. A., Sylvester-Bradley, R., and Rochford, A. D. H.: Availability of nitrogen after fertilizer applications to cereals, J. Agr. Sci., 136, 141-157, 2001.

Lesschen, J., Stoorvogel, J., Smaling, E., Heuvelink, G., and Veldkamp, A.: A spatially explicit methodology to quantify soil nutrient balances and their uncertainties at the national level, Nutr. Cycl. Agroecosys., 78, 111-131, 2007.

Lidén, R. and Harlin, J.: Analysis of conceptual rainfall-runoff modelling performance in different climates, J. Hydrol., 238(34), 231-247, 2000

Liu, J., Williams, J. R., Zehnder, A. J. B., and Yang, H.: GEPIC - modelling wheat yield and crop water productivity with high resolution on a global scale, Agr. Syst., 94, 478-493, 2007.

Liu, J., Zehnder, A. J. B., and Yang, H.: Historical trends in China's virtual water trade, Water Int., 32, 78-90, 2007.

Liu, J., Zehnder, A. J. B., and Yang, H.: Global consumptive water use for crop production: The importance of green water and virtual water, Water Resour. Res., 45, W05428, doi:10.1029/2007WR006051, 2009.

Liu, J., You, L., Amini, M., Obersteiner, M., Herrero, M., Zehnder, A. J. B., and Yang, H.: A high-resolution assessment on global nitrogen flows in cropland, P. Natl. Acad. Sci., 107(17), 80358040, 2010.

Liu J. and Yang H.: Spatially explicit assessment of global consumptive water uses in cropland: green and blue water, J. Hydrol., 384, 187-197, 2010.

Ma, W., Li, J., Ma, L., Wang, F., Sisak, I., Cushman, G., and Zhang, F.: Nitrogen flow and use efficiency in production and utilization of wheat, rice and maize in China, Agr. Syst., 99, 53-63, 2009.

McGuire, V. L.: Water-level changes in the High Plains Aquifer, predevelopment to 2005 and 2003 to 2005: U.S. Geological Survey Scientific Investigations Report 2006-5324, available at: http://pubs.usgs.gov/sir/2006/5324/, 2007.

Mitchell, T. D. and Jones, P. D.: An improved method of constructing a database of monthly climate observations and associated high-resolution grids, Int. J. Climatol., 25, 693-712, available at: http://csi.cgiar.org/cru/, 2005.

Molden, D. (Ed.): Water for food, water for life: A comprehensive assessment of water management in agriculture, Earthscan, London, UK, 2007.

Monfreda, C., Ramankutty, N., and Foley, J. A.: Farming the planet: 2. Geographic distribution of crop areas, yields, physiological types, and net primary production in the year 2000, Global Biogeochem. Cy., 22, GB1022, doi:10.1029/2007GB002947, www. geog.mcgill.ca/landuse/pub/Data/175crops2000/, last access: 18 September 2008.

Norse, D.: Non-point pollution from crop production: Global, regional and national issues, Pedosphere, 15(4), 499-508, 2005.

Noulas, Ch., Stamp, P., Soldati, A., and Liedgens, M.: Nitrogen use efficiency of spring wheat genotypes under field and lysimeter conditions, J. Agron. Crop Sci. 190, 111-118, 2004. 
Oki, T. and Kanae, S.: Virtual water trade and world water resources, Water Sci. Technol., 49(7), 203-209, 2004.

Peck, J. C.: Groundwater management in the High Plains Aquifer in the USA: Legal problems and innovations, in: The agricultural groundwater revolution: Opportunities and threats to development, edited by: Giordano, M. and Villholth, K. G., CAB International, Wallingford, UK, 296-319, 2007.

Pena, R. J.: Wheat for bread and other foods, in: Bread wheat: Improvement and production, Food and Agriculture Organization, edited by: Curtis, B.C., Rajaram, S., Macpherson, H. G., Rome, www.fao.org/docrep/006/y4011e/y4011e00.htm\# Contents, last access: 20 April 2009.

Peterson, J. and Bernardo, D.: High Plains regional aquifer study revisited: A 20 year retrospective for Western Kansas, Great Plains Studies, Centre for Great Plains Research: A Journal of Natural and Social Sciences, available at: http://digitalcommons.unl.edu/ greatplainsresearch/662, 2003.

Pingali, P. L. (Ed.): CIMMYT 1998-99 World wheat facts and trends. Global wheat research in a changing world: Challenges and achievements, International Maize and Wheat Improvement Center, Mexico, available at: http://apps.cimmyt.org/research/economics/map/facts_trends/ wheatft9899/pdf/WheatF $\backslash \&$ T99cont.pdf, 1999.

Portmann, F., Siebert, S., Bauer, C., and Döll, P.: Global data set of monthly growing areas of 26 irrigated crops. Frankfurt Hydrology Paper 06, Institute of Physical Geography, University of Frankfurt, Frankfurt am Main, Germany, available at: http://www.geo.uni-frankfurt.de/ipg/ag/dl/ f_publikationen/2008/FHP_06_Portmann_et_al_2008.pdf, 2008.

Postel, S. L.: Entering an era of water scarcity: The challenges ahead, Ecol. Appl., 10(4), 941-948, 2000.

Riley, W. J., Ortiz-Monasterio, I., and Matson, P. A.: Nitrogen leaching and soil nitrate, and ammonium levels under irrigated wheat in Northern Mexico, Nutr. Cyc. Agroecosys., 61, 223-236, 2001.

Romaguera, M., Hoekstra, A. Y., Su, Z., Krol, M. S., and Salama, M. S.: Potential of using remote sensing techniques to global assessment of the water footprint of crops, Remote Sens., 2(4), 1177-1196, 2010.
Roy, R. N., Misra, R. V, Lesschen, J. P., and Smaling, E. M. A.: Assessment of soil nutrient balance: approaches and methodologies, FAO Fertilizer and Plant Nutrition Bulletin, 14, FAO, Rome, 2003.

Sacks, W. J., Deryng, D., Foley, J. A., and Ramankutty, N.: Crop planting dates: An analysis of global patterns. Global Ecol. Biogeogr., data available at: http://www.sage.wisc.edu/download/ sacks/ArcINFO5min.html, last access: 9 September 2009, in review, 2009.

Schuol, J. and Abbaspour, K. C.: Using monthly weather statistics to generate daily data in a SWAT model application to West Africa, Ecol. Model., 201, 301-311, 2007.

Siebert, S. and Döll, P.: The global crop water model (GCWM): Documentation and first results for irrigated crops, Frankfurt Hydrology Paper 07, Institute of Physical Geography, University of Frankfurt, Frankfurt am Main, Germany, available at: www.geo.uni-frankfurt.de/ipg/ag/dl/f_publikationen/ 2008/FHP_07_Siebert_and_Doell_2008.pdf, 2008.

Siebert, S. and Döll, P.: Quantifying blue and green virtual water contents in global crop production as well as potential production losses without irrigation, J. Hydrol., 384, 198-207, 2010.

Smaling, E. M. A., Roscoe, R., Lesschen, J. P., Bouwman, A. F., and Comunello, E.: From forest to waste: Assessment of the Brazilian soybean chain, using nitrogen as a marker, Agric Ecosyst. Environ., 128, 185-197, 2008.

Webster, C. P., Poulton, P. R., and Goulding, K. W. T.: Nitrogen leaching from winter cereals grown as part of a 5-year ley-arable rotation, Eur. J. of Agron., 10, 99-109, 1999.

Williams, J. R., Jones, C. A., Kiniry, J. R., and Spanel, D. A.: The EPIC crop growth-model, T. ASAE, 32(2), 497-511, 1989.

WWAP: The United Nations World Water Development Report 3: Water in a changing world, World Water Assessment Programme, UNESCO Publishing, Paris/Earthscan, London, 2009.

Yang, H., Wang, L., Abbaspour, K. C., and Zehnder, A. J. B.: Virtual water trade: an assessment of water use efficiency in the international food trade, Hydrol. Earth Syst. Sci., 10, 443-454, doi:10.5194/hess-10-443-2006, 2006.

Zwart, S. J. and Bastiaanssen, G. M.: Review of measured crop water productivity values for irrigated wheat, rice, cotton and maize, Agr. Water Manage., 69(2), 115-133, 2004. 